\title{
FACTORS INFLUENCING GRADUATE STUDENTS' PERCEPTION OF ONLINE AND DISTANCE LEARNING IN NEPAL
}

\author{
Parshu Ram UPADHAYAYA \\ ORCID: 0000-0002-8752-6480 \\ Department of Information and Communication Technology Education \\ Tribhuvan University \\ Kathmandu, NEPAL
}

Bishnu SHARMA

ORCID: 0000-0002-6480-6973

Central Department of Education

Tribhuvan University

Kathmandu, NEPAL

Yagya Prasad GNAWALI

ORCID: 0000-0002-4127-5495

Department of Mathematics Education

Tribhuvan University

Kathmandu, NEPAL

Dr. Shashidhar BELBASE

ORCID: 0000-0003-3722-756X

College of Education

United Arab Emirates University

Al Ain, Abu Dhabi, UNITED ARAB EMIRATES

Received: 24/07/2020 Accepted: 22/01/2021

\begin{abstract}
This study explored the perception of online and distance learning (ODL) experienced by postgraduate students in Nepal during the COVID-19 pandemic in 2020. An online survey on Graduate Student Perception on ODL (GSPODL) with a five-point Likert-scale was designed and administered to 71 postgraduate (57 male and 14 female) students of science education in a public higher education institution in Nepal in spring 2020. A Principal Component Analysis with rotation in Varimax Kaiser Normalization was employed in the Statistical Package for Social Sciences (IBM SPSS 26) to construct six major components of students' perception of course delivery and participation. These components were- Quality, Opportunity, Relevance, Development, Support, and Challenges. Mann-Whitney U Test or Kruskal-Wallis Test at 0.05 level of significance showed that the participants' views about Quality, Opportunity, Relevance, and Support were significantly different across their place of Residence (rural and urban residences). Likewise, there was a significant difference in their views on the Relevancy of the ODL with respect to Device Use. There was no significant difference in their views across the variables Gender, Ethnicity, School Type, and Device Use in all other criteria. These results demonstrated that participants' hometown location made a big difference in their perception of online and distance classes' Quality.
\end{abstract}

Keywords: Online and distance education, flexible learning, teacher education, Nepal. 


\section{INTRODUCTION}

An early form of distance education started as correspondence education that could be traced back to 1728 . However, there is controversy if such correspondence could be considered a distance education because of a lack of concrete evidence of two-way communications during learning and teaching, even with the mails (Kentnor, 2015). Nonetheless, formal distance education was in practice since a long time ago (in the 1800s) in the US through correspondence programs (Gunawardena \& McIsaac, 2008), and it began in England in 1840 with lessons through mails (Molenda, 2008). In Germany, distance education was established to teach language through correspondence mode in 1856 (Demiray \& Isman, 2001). By 1892, distance education through correspondence gained momentum with the help of post offices (Drexel Univeristy, 2017). Then it took different paths through the advancement of education through the introduction of radio in 1922, a television in 1953, a telephone in 1965, Internet in 1969, courses with computers in 1981, and worldwide web (www) in 1989 (Drexel University, 2017). It expanded rapidly with the online course offerings of colleges and universities (Drexel University, 2017). There were 6,932,074 students enrolled in at least one online and distance education course at higher education institutions in the US in the 2018-19 academic year (National Cener for Educaitonal Statisticas [NCES], 2019). However, the pattern of online and distance learning has changed with mixed results. For example, enrollment in the distance learning programs in the US universities was growing (NCES, 2019), but it was decreasing in the UK and Australia by $5 \%$ in the 2017-18 academic year (Kemp, 2019).

As open and distance learning at higher education gained popularity despite some ups and downs, many countries began to offer online and distance (ODL) programs to provide better access to people who could not afford regular education. Nepal's neighboring country, India, started ODL programs establishing open universities in 1982 with the establishment of Dr. B. R. Ambedkar Open University, Hyderabad (MHRD, India, 2020). Then they opened Indira Gandhi National Open University (IGNOU) in 1985 to provide nationwide ODL programs with the central government initiative. India had about 22\% (more than 3.6 million) of the total enrollment of higher education students in the ODL mode in 2012 (Suneja, 2012). This number reached 4.2 million in the year 2019 (Qayyum \& Zawacki-Richter, 2019). Similarly, the number of enrollment in the ODL system in China has also grown by $8.8 \%$ annually in the last decade (2004 to 2016) (Qayyum \& Zawacki-Richter, 2019).

When the world was making rapid progress in ODL, Nepal, too, marched its step with the New Education System Plan 1971(NESP), which mandated training primary school teachers. These teachers had degrees of school leaving certificate (SLC), which was the tenth-grade certificate, and had permanent positions as primary school teachers (Pradhan, 2011). In general, they suffered from geographical obstruction and the absence of transportation to reach the training centers while working at schools. The USAID, UNICEF, and British Council came together with a plan to train these teachers from a distance. Radio Education Teacher Training Project was started in 1978 with technical and financial support from the USAID (Holmes, 1990). It took quite a while to prepare the design and materials for the training. Eventually, Radio Education Program was conducted from 1984 until 1989 for training the primary school teachers with the financial and technical support of USAID (Holmes, 1990). With the growing need for teacher training, the Institute of Education (IOE) started another program called 'teacher training' through distance learning in 1976-77. This program was mainly to upgrade the competencies of the primary school teachers, preparing them for grade-teaching in the remote zones of Nepal (Pradhan, 2011). Despite these efforts, Nepal could not make remarkable progress in the ODL for a long time because the higher education institutions remained inactive to develop such programs. The government could not deliver any policy and guidelines to promote ODL until 2007.

The effectiveness of the ODL in a country is severely affected by the government's plans and policies regarding such programs. For example, the ODL policy affected the quality of such programs in South Korea, China, and Turkey (Gunduz, Kursun, Karaman, \& Demirel, 2020). The Government of Nepal, Ministry of Education (MoE) approved ODL policy on January 4, 2007, to provide "full access to schools and higher education to learners having diverse and special needs, especially of out-of-school children, deprived groups, working people, and housewives through open and distance learning systems as supplementary to the existing system of education" (MoE, 2007, p. 1). This policy addressed the educational needs of people who are unable to present at physical campuses due to geographical barriers, gender discrimination, 
poverty, and marginalized citizens. The ODL policy had four distinct agendas. The first agenda was about increasing access to education for all kinds of learners/students. The second agenda aimed to improve the quality of education by integrating the ODL system into the existing traditional face-to-face education. The third agenda emphasized continuing education as a part of lifelong learning and teachers' professional development through flexible modes of the ODL and community learning centers. The fourth agenda was related to the certification of informal knowledge and skills through an appropriate mechanism. This way, the policy had initiated several other provisions of education through Radio, FM, and TV channels and networking with other national and international institutions that offer ODL programs (MoE, 2007). With such efforts, the Ministry of Education, Science, and Technology (MoEST) has launched an e-learning portal (https://learning.cehrd.edu.np/) for grades 1 to 10 students in schools. The portal has been launched for students who have been deprived of education due to the fear of COVID-19 (MoEST, 2020).

The Government of Nepal (GoN) established Nepal Open University (NOU) in 2016 as an autonomous and well-organized higher education institution (GoN, 2016). The preamble of the act of NOU states that the establishment of the university was an appropriate initiative to promote high-quality teaching, learning, and research through new approaches of open education technology, methods, and techniques. The university aims to provide higher education access to the general public to develop competent human resources with knowledge, skills, and technological competencies (GoN, 2016). Currently, NOU has launched some undergraduate and graduate (masters) programs under three distinct faculties - Faculty of Management and Law, Faculty of Social Science and Education, and Faculty of Science, Health, and Technology (NOU, 2020). About 1,200 students enrolled in different programs at NOU by the end of 2019 (Dhakal, 2019). This number reached nearly 2000 by July 2020 (Panta, Padam Raj, A NOU Employee; Personal Communication on July 22, 2020).

Besides Nepal Open University, other universities, such as Tribhuvan University and Kathmandu University, have launched some of their programs in ODL mode. For example, the School of Education Kathmandu University (KUSOED) has recently launched a one-year Masters of Education in English Language Teaching, which can be delivered both face-to-face and online mode as per the demand of the students who enroll in the program (KUSOED, 2020 a). During the COVID-19 Pandemic, KUSOED issued a guideline for its faculty members and students to run all the classes in online mode (KUSOED, $2020 \mathrm{~b}$ ).

Tribhuvan University established the Open and Distance Education Center (ODEC) in 2015 as an independent unit within its organizational framework to provide access to higher education to the general public through flexible open and distance learning modes. The center has run a four-semester Two-Year Master of Education program in Mathematics and English Language Teaching. It also offers a short course on academic writing (ODEC, 2020). Likewise, some constituent campuses of Tribhuvan University have run the master's program in the ODL mode. For example, Mahendra Ratna Campus Tahachal has conducted a one-year (two-semesters) Master's Degree program in science education through the ODL mode. Currently, there are 92 students enrolled in the program from 33 districts of Nepal (Dhakal, Krishna Prasad, Chief of Mahendra Ratna Campus Tahachal, Personal Communication on April 25, 2020). The campus also has been offering a one-year (two-semester) postgraduate diploma (PGD) in social study and mathematics education to train inservice teachers through the ODL mode. These were signature programs for the university to continue online and distance learning without any hassle during the COVID-19 Pandemic when other faceto-face programs much suffered from confusion, chaos, and mismanagement.

There are some Kathmandu-based private institutes that offer open learning programs affiliated with national or foreign universities. For example, the Institute of Open Learning (IOL) is affiliated with Purbanchal University, and International Center for Academics (ICA) is affiliated with Indira Gandhi National Open University of India. The IOL offers a one-year bachelor's in education (B.Ed.) program for inservice teachers who already have a bachelor's degree in non-education major (IOL, 2020). The ICA offers certificate, bachelor's, postgraduate diploma (PGD), and master's programs in collaboration with different higher education institutions, such as Indira Gandhi National Open University (ICA, 2020).

Although there are some programs and initiatives in ODL in Nepal, there is a massive scarcity of research literature in the area of online and distance education in Nepal. Few articles (e.g., Pangeni, 2016; Chouhan, 2014) and some graduate theses (e.g., Sapkota, 2012) are good to study some background in the distance 
and online education in Nepal but are not adequate to understand the prospects and practical problems or challenges due to lack of empirical data or lack of focus on the main issues of ODL. This research paper's primary objective was to investigate the perceptions of ODL students in Nepal. This study was designed to answer the following research question: How do postgraduate students perceive the ODL in Nepal? In the rest of the paper, first, we presented a review of the related literature. Second, we explained the methodology of this study. Third, we analyzed the results of the investigation. Then, finally, we discussed the findings and presented this study's conclusion.

\section{REVIEW OF LITERATURE}

This section presents a review of some literature from 2009 to 2020 that included different countries and contexts. It emphasized the study's areas, aims, methodological tools, and a few findings of the studies.

Lee, Yoon, and Lee (2009) studied learners' acceptance of e-learning in South Korea at a paradigm shift from teacher-centered to student-centered education. They studied four independent variables that were instructor's characteristics, teaching materials used in the classrooms, design of learning contents, and playfulness in the class. They also studied two belief variables-- perceived usefulness and ease of use of e-learning, and the dependent variable was the intention to use e-learning. They designed a survey questionnaire using five points Likert scale. They used Cronbach's alpha coefficient to test the internal consistency among the items. They distributed 250 questionnaires to undergraduate students who had some course experiences in e-learning in a comprehensive university in South Korea. They received 214 valid responses from the participants. They used SPSS 12 to analyze the data by using factor analysis with principal components and varimax rotation method. The study results revealed that instructor characteristics and teaching materials positively correlated to the perceived usefulness of e-learning. They further found that learner's acceptance of e-learning and playfulness positively affected the intention to use e-learning. They found that perceived ease of use was the weakest among the seven hypotheses.

Firat (2016) examined the e-learning autonomy of distance education students in the e-learning environment. Firstly, the researcher developed an e-learning scale and established the validity and reliability of the scale by the piloting of the tool with the 1152 participants from Anadolu University, in an open education system. The internal consistency was measure by coefficient of reliability with Cronbach's $\mathbb{Q}=0.952$. The researcher then administered the survey to a large sample of 3,292 students frosm 42 different programs (6 undergraduate and 36 associate degree programs) during the 2014-2015 academic year. The researcher developed an e-LAS scale to analyze the autonomy of the students in e-learning environments. He used percentage (\%), frequency (f), mean, parametric independent sample t-test, and one-way ANOVA. $\mathrm{He}$ conducted the statistical tests in IBM SPSS 22. He computed the Kaiser-Meyer-Olkin (KMO) value ranging between 0 and 1 . In this study, Firat (2016) reported that the KMO value was 0.943 . The Bartlett's Sphericity test result showed the Chi-square value 10329.547 which was significant at $p<0.001$. The results revealed that students' autonomy in e-learning environments did not statistically vary significantly with their programs' characteristics. Moreover, the e-LAS scores were compared by gender with the help of an independent sample t-test. The result showed that there was no significant difference between the e-LAS scores when compared by gender. The majority of them met both workload flexibility (strongly agree $34.6 \%$ and agree $27.1 \%$ ) and possibly studying at the place of residence (strongly agree $40.8 \%$ and agree $20.4 \%$ ). These results indicated that distance education among people of different ages and those living in rural areas was entirely justified (Firat, 2016).

Vasilevska, Rivza, Pivac, Alekneviciene, and Parlinska (2017) studied the demand for distance education at an eastern and central European higher education. The study aimed to identify the need for the distance learning model to identify its problems and development trends. They took five countries: Latvia, Lithuania, Serbia, Poland, and Belarus, for this study. They included four main issues like adaptability, technical capabilities, computer literacy, and self-control and motivation as the study variables. The study employed a structured survey research design with the five-point Likert scale to collect the data. The total number of respondents was 877, which included 491 females and 386 males. They analyzed the data in SPSS 16 and Excel spreadsheets for descriptive statistics. The findings showed that $42 \%$ of the students were completely satisfied, $32 \%$ would prefer the traditional form of education, while $26 \%$ of respondents expressed that the 
model was not suitable for them. The study also revealed that the traditional teaching method of education based on communication between teachers and students was more demanding than distance mode. The participants agreed that distance education at a higher level provides strong technical skills and independent self-learning environments.

Markova, Glazkova, and Zabarava (2017) studied quality issues in distance learning. This study aimed to present the result of the survey conducted at the Ural State University of Economics and Ural Federal University in Russia. They used a survey design on a sample of over 830 postgraduate students involved in the distance learning programs. The students' age was $19-54$ years, covering 27 big and small towns of the Ural region in 2015 and 2016. The questionnaire included the items related to the area of use of technology and resources, effectiveness of distance learning, motivation, challenges, learner/instructor communication, interaction, evaluation and self-assessment, and satisfaction of the students in distance learning (Markova et al., 2017). The results indicated that postgraduate students positively evaluated their distance learning experiences, although they faced a few learning challenges, especially communication and instruction. The results revealed that technology does not teach students, but technical support plays a crucial role in distance learning and reducing student's anxiety. Faculty qualifications were essential factors in upgrading and creating the quality of the distance program. Over $70 \%$ of the participants expressed that guidance and counseling, and maintaining emotional contact with instructors were vital. Therefore, they highly rated the supporting environments. Lastly, the survey pointed out a lack of emotional communication with the teachers $(31.1 \%)$, a lack of teacher control (20.5\%), and a sense of isolation (13.1\%) were some of the drawbacks of distance learning (Markova et al., 2017).

Cabi and Kalelioglu (2019) studied students' perspectives on an online course concerning attitude, readiness, and thoughts. The objective of their study was to examine the effect of an online course on the students' attitudes, thoughts, and readiness to learn the subject matter through a mixed-method study design with pre-test, intervention, and post-test on a group of 266 undergraduate and associate degree students. The results of the study indicated that there was a significant difference in the pre-test and post-test results on computer/Internet self-efficacy and self-directed learning. Also, the study showed that there was a significant effect of students' familiarity and escape attitude on e-learning. The qualitative data showed that several students found benefits of distance education in terms of accessibility and availability of the course materials.

Serhii, Vladyslav, Viacheslav, Kateryna, and Svitlana (2020) studied the realities and prospects of distance education at higher education institutions in Ukraine. The study outlined the current status of distance learning, especially in Ukraine. This study used a survey design, including 102 students as participants. The survey questionnaire was prepared to cover the students' attitudes towards distance learning, organization, advantages, and disadvantages. The survey questionnaire was based on the current state of higher education in Ukraine. They designed the survey tool in Google Form and shared the survey link with the respondents. They analyzed the data using Microsoft Office Excel spreadsheets. They found that students at all four higher education institutions were familiar with distance education and used this technology, and most of them preferred mixed learning. The results of the study revealed that the students were able to integrate their work, and they could self-determine. However, the study time and place were the significant advantages of distance learning. It also revealed that the student's self-motivation was needed in distance learning, which indicated a major disadvantage of it.

Ali (2020) studied online and remote learning in higher education institutes. The purpose was to examine how teaching and learning could be continued during the COVID-19 pandemic time. Almost all the countries in the world had been affected by COVID 19, and educational institutions were being closed physically and socially. Regarding this pandemic situation, some educational institutions started online learning. In this study, Ali utilized the data from the World Health Organization (WHO) when 213 countries were affected by the virus as of 12 April 2020. At the moment, New York University Shanghai and Duke Kunsan University utilized Zoom applications and other video conferencing tools instead of face-to-face teachinglearning. Ali (2020) conducted a meta-analysis of the world context, politics of resistance, infrastructure support, staff readiness, student accessibility, and the confidence of the teaching staff, which played a vital role in ICT integrated learning. He added that ICT became an integral part of everyday life, and it became a means to transform the learning environment. He further revealed that the blended learning model attracted existing political agendas, and establishing such a mode was better than other alternatives. Staff readiness 
and motivation also helped in the successful assimilation of technology in higher education institutions. Furthermore, he found that students had a special bonding with ICT.

Reich and Tobias (2020) evaluated the access, quality, and equity in online learning based on a case study of a blended professional degree program. The study's main aim was to examine students' experiences in one Massive Open Online Courses (MOOC)-based on the blended professional degree program. They formulated hypotheses to address the study's aim and used a mixed-method design with a motivation to develop MOOC-based professional online, blended learning. A total of 81,000 students participated in the chain management of MOOCs. Among them, 7,999 were verified students paid the fee at least one course for an opportunity to get certificates. Likewise, 3,804 obtained the certificate for at least one course in Micro Master sequence, 622 got a certificate Micro, 130 applied for the Accelerated Master Program at MIT, and 40 participants enrolled and arrived on campus in a blended cohort program. They designed survey questions including age, gender, and level of education and variety of data sources, including the five MOOCs courses in the Micro Master program. They conducted a semi-structured interview at the beginning of January 2018. They coded the qualitative data using the grounded theory approach. They coded each interview independently by three raters (one author and two undergraduate research assistants) to identify the data's theme. They calculated Cohen's kappa, and the overall pooled kappa from all of the interviews was 0.72 . They analyzed log data from edX of all students who participated in one of the five MOOCs courses in the program (with eight total courses run) and differences in students' activities using a non-parametric test (Wilcoxon and Mann-Whitney Test). They found that self-regulated habits were fostered and supported through socio-environmental factors. Overall, blended students felt that online courses provided quality learning experiences. The blended group mentioned the job-oriented content, the flexibility of the courses, low cost, and affordance in technology as important aspects of a blended approach. Blended students got higher grade in their residential course than other students $(\mathbb{X}=0.11, \mathrm{t}=3.26, \mathrm{df}=3374, \mathrm{p}<0.01)$ and students from outside the program who studied in the same classes $(\mathbb{Q}=0.25, \mathrm{t}=10.42, \mathrm{df}=3374, \mathrm{p}<0.01)$. The study's results revealed that at the end-of-semester survey, $66 \%$ of blended students said they learned from teamwork and positively influenced their intellectual growth.

Trespalacios and Uribe-Florez (2020) reported a study on graduate students' experiences of sense of community in an online study program. They studied two research questions that focused on students' rating of the online course and their sense of community, and their perception of the relevance of online learning. They applied a quantitative survey design with a classroom community survey, end-semester course evaluation and semi-structured interviews on twelve graduate students at a university in the US. The findings of the study showed that the participants (graduate students) had a high sense of community with a high value of connectedness. Almost all the participants had a high satisfaction rating for the end-of-semester course evaluation, indicating that they highly valued the performance of the course instructors. The results indicated that e-learning was an effective tool for the graduate program of educational technology.

\section{METHODOLOGY}

This study employed an online quantitative survey design with multiple-choice five-point Likert scale items named Graduate Student Perception of ODL (GSPODL). Survey research design is a procedure in quantitative research in which the researcher administers a questionnaire to a sample of the population (Creswell, 2012). A sample survey is a technique to collect quantitative data by administering questionnaires to the sample of a population under the study. The questionnaires can be adopted into an online platform such as Google Form or SurveyMonkey.com because they are convenient and flexible (Behrend, Sharek, Meade \& Wiebe, 2011).

\section{Construction of the Tool}

First, a structured survey questionnaire was developed by the researchers in eighteen different areas from our experiences, including the students' voices and concerns with ODL. The items in the questionnaire were discussed among the researchers to improve the relevancy and sufficiency of the items. Altogether, 83 questions (items) were listed for selection, modification, and finalization in Google Form to construct a scale 
on Graduate Student Perception of ODL (GSPODL). After a lengthy discussion among the four researchers, it was finalized and shared the developed scale with two senior experts and colleagues at Tribhuvan University at the Online and Distance Learning Center. Some minor corrections were made from their suggestion and feedback, and selected the 40 best questions out of 83 after removing 43 questions according to the recommendations of experts to keep them aligned with the research problems and issues (Please, see in Appendix).

\section{Administration of Survey}

Altogether there were 92 students enrolled in a postgraduate two semesters M.Ed. Science Education program at the ODL Center in a program at Mahendra Ratna Campus Tahachal, Kathmandu. They were from 33 districts and seven provinces of Nepal. We categorized them into two groups (group A and group B), whereas 78 students regularly presented in the ODL class, and the rest of the others dropped out of the program. Among the 78 regular students, 71 students participated in the study; amon them 64 were male and 14 were female students. Among them, 32 students were from rural areas, and the remaining 39 were from urban areas of Nepal. As a teacher, counselor, and IT person, the researchers were frequently in contact with all the students. Table 1 shows the distribution of participants across Gender, Age Group, Ethnicity, Hometown, School Type, and Device Use.

Table 1. Distribution of Research Participants across Gender, Age Group, Ethnicity, Hometown, School Type, and Device Use

\begin{tabular}{|c|c|}
\hline Gender: Male 57 and Female $=14$ & Hometown: Rural $=32$ and Urban $=39$ \\
\hline Age Group: $\begin{aligned} 26-30= & 15,31-35=42,36-40=12, \text { and } 40 \\
& - \text { Above }=2\end{aligned}$ & $\begin{array}{c}\text { School Type: Community }=16, \text { Institutional }=28, \text { Public }=20, \\
\text { and Other }=7\end{array}$ \\
\hline $\begin{aligned} \text { Ethnicity: Brahman }= & 35, \text { Kshetree }=15, \text { Baishya }=21, \\
& \text { Sudra }=0 .\end{aligned}$ & $\begin{array}{l}\text { Device Use: Laptop and Mobile }=44 \text {, Laptop Only }=21 \\
\text { Mobile Phone }=4 \text {, Desktop computer }=2\end{array}$ \\
\hline
\end{tabular}

The survey link was shared with the participants in Microsoft Teams online virtual classroom platform in both A and B sections on the same date and time. All the students were informed about the purpose of the study and the use of the data. They were requested to fill up the questionnaire during their free time voluntarily. They were provided with one week's time to decide their participation and to have queries about the survey questionnaires (Richards \& Schwartz, 2002). Their participation in the survey was followed by informed consent while responding to the questionnaire (GSPODL) in Google Form. The participants had a choice to either write their names on the form or keep them anonymous. There was a follow-up communication with them to clarify any questions they had and observe their progress in responding to the questionnaire. Finally, 71 students submitted the completed questionnaire (GSPODL) through online submission within two weeks.

\section{Coding Data in SPSS}

The survey data were retrieved in Excel spreadsheets from the Google Form. The data were uploaded into IBM SPSS 26 to analyze the collected data. First, the categorical data were coded into numerical form. The items were coded with the nominal categories, such as Gender, Hometown, Ethnicity, Age Group, School Type, and Device Use with numbers 0 and 1 for binary categories (Gender as male and female and Hometown as rural and urban) and 1,2, 3, 4 as variables in multidimensional categories, such as Age Groups 21-25 as 1, 26-30 as 2, 31-35 as 3, 36-40 as 4 and above 40 as 5. Likewise, the Ethnicity of Brahman was coded as 1, Kshetree as 2, Baisya as 3, and Sudra was coded as 4. The School Type, such as Public was coded as 1, Institutional as 2, Community as 3, and Other as 4. The Device Use like MobileAndLaptop was coded as 1, Laptop as 2, Phone as 3 and Desktop as 4 . The Likert scale items were coded in IBM SPSS 26 with Strongly Disagree as 1, Disagree as 2, Neutral as 3, Agree as 4, and Strongly Agree as 5. The multidimensional categorical variables (Ethnicity, Age Group, School Type, and Device Use) needed 
additional coding with dummy variables to facilitate Multiple Linear Regression (MLR) analysis. Dummy variables were created for these independent variables to convert them into multiple binary variables. For example, Ethnicity had four groups Brahman, Kshetree, Baisya, and Sudra, and each was coded with 0 and 1 under separate columns as new variables.

\section{Data Analysis}

First, an analysis of dimension reduction was carried out from the 40 Likert scale data to find fewer but more meaningful groups or categories of the items. The analysis steps were followed as - analyze, dimension reduction, factor, selection of 40 items as variables, Descriptives (initial solution, coefficients, KMO and Bartlett's test of sphericity), and Extraction (principal components, correlation matrix, unrotated and roated factor solutions, scree plot, a fixed number of factors to extract 6 , maximum iteration for Convergence at 25). Then, rotation method Varimax with Kaiser Normalization was applied with a display of rotated matrix, display factor score coefficient matrix, excluding any missing cases listwise, coefficient display to be sorted by size, and suppress coefficients smaller than absolute value 0.4 .

There were 13 items loaded with negative coefficients in the rotated matrix. A reverse coding was applied on the Likert scale values of the respective itesm to change the negative statements into positive to resolve the issue of negatively loaded items with some components. After replacing the reversed items in place of the original item, respectively, then it was found positive coefficient values of all factors in the rotated matrix. There were five items that did not load with any of the six factors or components due to low factor loading coefficients $(<0.40)$. Therefore, these items were not included in further analysis. The six new composite variables were constructed from the components using the Transform function of Compute New Variables in the SPSS. The categorical variable measures were determined by averaging the item scores within each component. These six new component variables and the other six categorical variables (Gender, Age Group, Ethnicity, Location, School Type, and Device Use) were used for further analysis-- hypothesis tests for group comparison and MLR analysis for determining significant predictors of dependent variables.

\section{FINDINGS}

\section{Principal Component Analysis}

After retrieving the survey data in an Excel spreadsheet and transferred it to IBM SPSS 26 from the Google Form, a test of the reliability of the survey results was conducted by using Cronbach's Alpha, and it was found to be 0.844 , which was at the acceptable level (higher than 0.6). A factor analysis was conducted with the extraction method of rotated Principal Component Analysis applying Varimax with Kaiser Normalization with the extraction of components based on eigenvalues more than one. This process provided us with ten possible components that had the eigenvalues higher than one. However, the coefficients of factor loading for the items at absolute value 0.4 distributed the items across the components that looked similar. Therefore, the scree plot was observed and identified six potential number of components from the six distinct elbows with eigenvalues greater than one (Figure 1). Then, the principal component analysis was applied again by fixing the number of components to be extracted as $9,8,7$, and 6 , and the best distribution of items was achieved across the components when the number of components was fixed at 6 with a rotation of items converged in ten iterations. The Kaiser-Meyer-Olkin measure of sampling adequacy for the principal component analysis was 0.652 , which was at the average level that can be accepted as valid with an eigenvalue greater than 1 . Also, Bartlett's Test of Sphericity with approximate Chi-square 1373.58 and degree of freedom 595 was significant $(\mathrm{p}<0.05)$ (Table 2). 


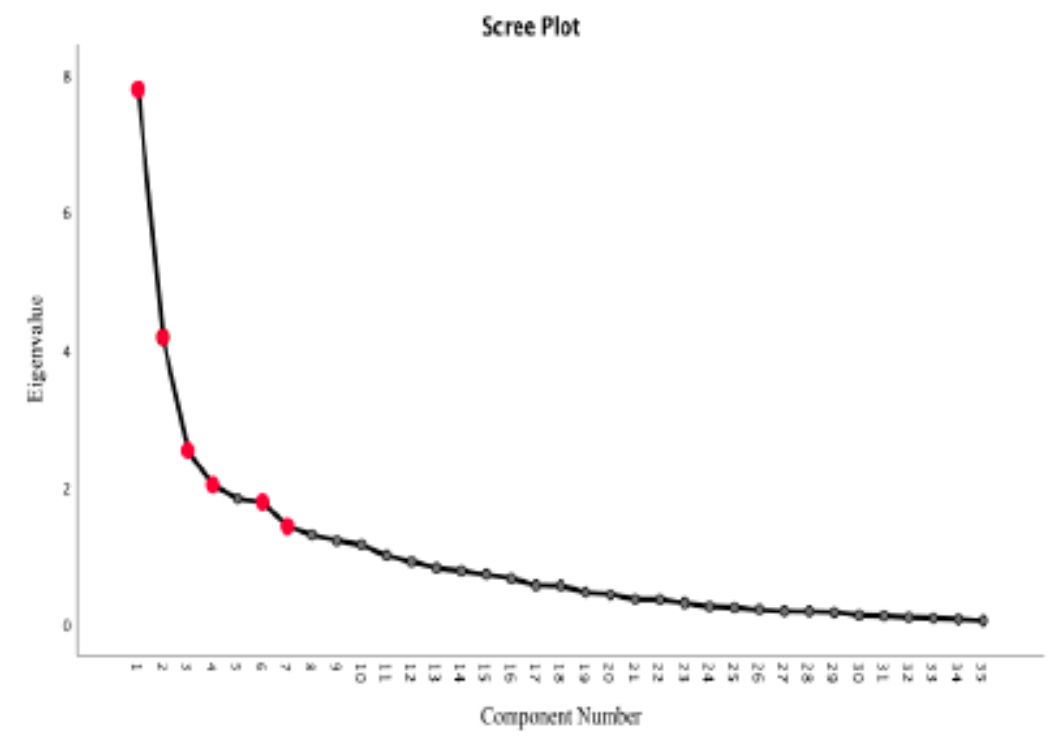

Figure 1. Scree Plot for Principal Component Analysis by Varimax with Kaiser Normalization

Table 2. KMO and Bartlett's Test for Sample Adequacy of Principal Component Analysis

\begin{tabular}{ccc}
\hline & \\
\hline & KMO and Bartlett's Test & .652 \\
Kartlett's Test of Sphericity & Approx. Chi-Square & 1373.580 \\
& df & 595 \\
& Sig. & .000 \\
\hline
\end{tabular}

The rotated factor loading for each component has been displayed in Table 3 with items loaded, coefficients, and their reliability coefficients (Cronbach's Alpha). Among the thirty-five items run for the principal component analysis, there were seven items loaded into the first component with factor loading coefficients between 0.437 and 0.847 (Table 3). Based on the nature of the majority of the components loaded into this component and the item with the highest loading coefficient, it was named as the Quality of the online and distance learning. The reliability coefficient (Cronbach's Alpha) of this component was found to be 0.82. Similarly, there were seven items loaded into the second component with minimum and maximum coefficients of 0.430 and 0.754 , respectively, with a reliability coefficient of 0.79 . This component was named as student Opportunity for learning through the ODL. The third component had six items loaded into it with a range of coefficients from 0.452 to 0.752 , with a reliability coefficient of 0.78 . It was named as Relevance of the ODL. Likewise, the fourth, fifth, and sixth components had factor loading coefficients from 0.481 to 0.734 and reliability coefficients $0.72,0.75$, and 0.74 , respectively. They were named as professional Development, student Support, and Challenges, respectively, based on the nature of the majority of the items loaded with them (Table 3). These six components were used as the new composite variables for further statistical analyses of independent samples test and MLR modeling. 
Table 3. Factor Loading from Rotated Components

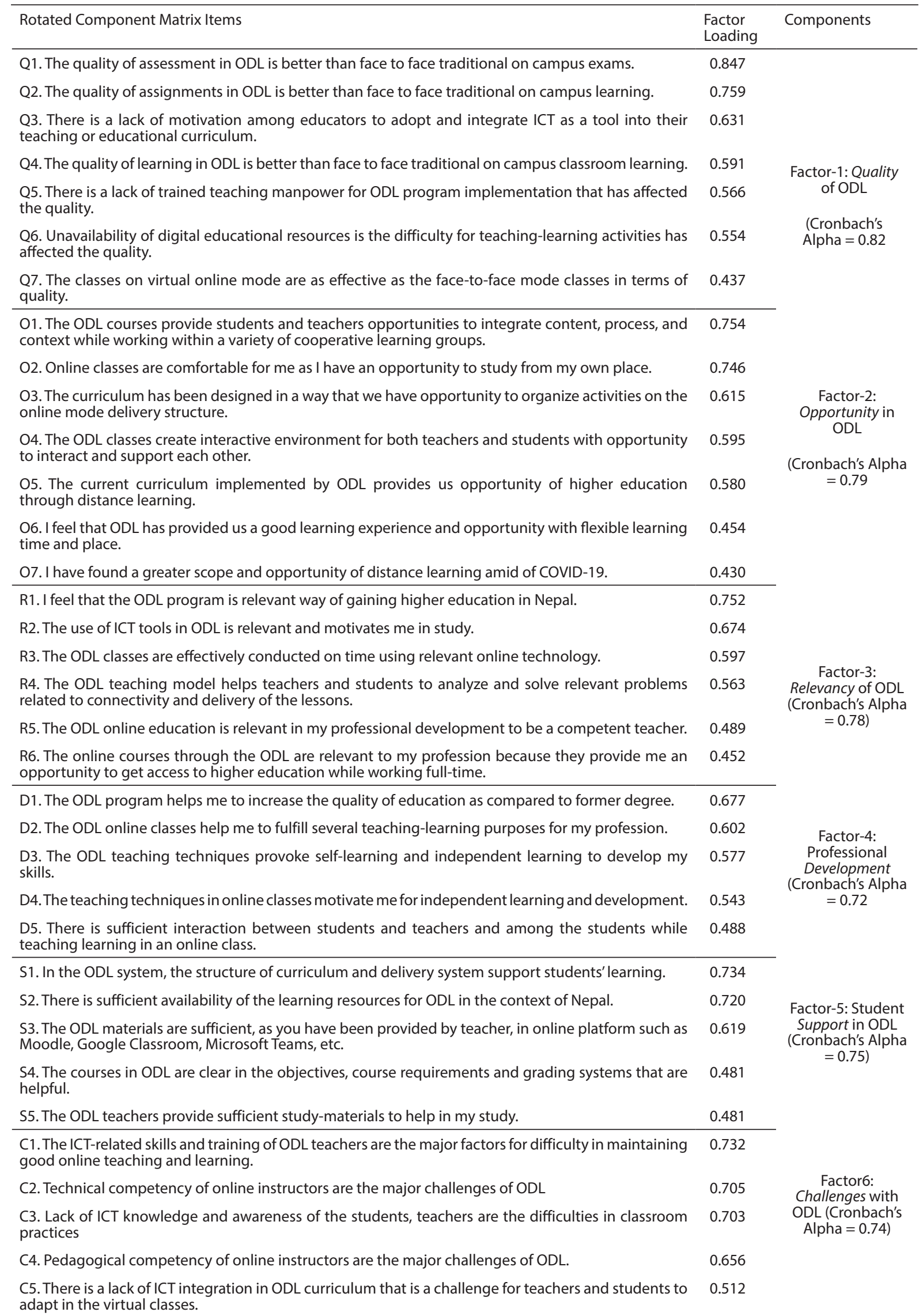

Extraction Method: Principal Component Analysis. Rotation Method: Varimax with Kaiser Normalization. Rotation converged in 10 iterations. 
The total variance explained for the Principal Component Analysis in Table 4 shows that the initial eigenvalues for each component ranged from 1.778 to 7.786 , all higher than 1 . The percentage of initial eigenvalues variance contributed by each component ranges from $5.081 \%$ to $22.245 \%$ with the first component accounted for the highest variance $(22.245 \%)$, and the sixth component accounted for the least variance (5.081\%) among the six components. However, the total cumulative variance explained only $57.508 \%$ of the total variance, indicating that the six factors partially explained the characteristics of the GSPODL-scale. How these variances changed from initial extraction to the rotated extraction has been demonstrated in Table 4

Table 4. Total Variance Explained for Principal Component Analysis

\begin{tabular}{|c|c|c|c|c|c|c|c|c|c|}
\hline \multirow[b]{2}{*}{ Components } & \multicolumn{3}{|c|}{ Initial Eigenvalues } & \multicolumn{3}{|c|}{$\begin{array}{l}\text { Extraction Sums of Squared } \\
\text { Loadings }\end{array}$} & \multicolumn{3}{|c|}{ Rotation Sums of Squared Loadings } \\
\hline & Total & $\begin{array}{c}\% \text { of } \\
\text { Variance }\end{array}$ & Cumulative\% & Total & $\begin{array}{c}\% \text { of } \\
\text { Variance }\end{array}$ & $\begin{array}{c}\text { Cumulative } \\
\%\end{array}$ & Total & $\begin{array}{c}\% \text { of } \\
\text { Variance }\end{array}$ & $\begin{array}{c}\text { Cumulative } \\
\%\end{array}$ \\
\hline Quality) & 7.786 & 22.245 & 22.245 & 7.786 & 22.245 & 22.245 & 4.094 & 11.697 & 11.697 \\
\hline Opportunity & 4.177 & 11.935 & 34.180 & 4.177 & 11.935 & 34.180 & 3.638 & 10.395 & 22.093 \\
\hline Relevance & 2.531 & 7.231 & 41.411 & 2.531 & 7.231 & 41.411 & 3.280 & 9.373 & 31.465 \\
\hline Development & 2.029 & 5.798 & 47.209 & 2.029 & 5.798 & 47.209 & 3.215 & 9.185 & 40.650 \\
\hline Support & 1.826 & 5.218 & 52.427 & 1.826 & 5.218 & 52.427 & 3.038 & 8.680 & 49.330 \\
\hline Challenges & 1.778 & 5.081 & 57.508 & 1.778 & 5.081 & 57.508 & 2.862 & 8.178 & 57.508 \\
\hline
\end{tabular}

\section{Student Perception of ODL}

A descriptive statistics (mean and standard deviation) were applied with one-sample t-test to determine if the mean differences were significant $s$ the items for each component. A null hypothesis test was conducted to examine if the participants' views had any significant difference in the six components and a composite perception concerning their Gender, Hometown, Age Group, Ethnicity, School Type, and the Device. Independent-Samples Mann-Whitney U Test was run to compare the participants' views on the seven variables concerning Gender and Hometown (two groups comparison). Similarly, the Independent-Samples Kruskal-Wallis Test was conducted to compare more than two groups. Both tests were conducted at the level of significance of 0.05 . The results of these tests in IBM SPSS 26 have been discussed under each category separately.

The MLR analyses were conducted to fit models of each of the six dependent variables (the six component variables) against the categorical (nominal) independent variables (Gender, Location, Age Group, Ethnicity, School Type, and Device Use). Additional dummy variables were created for the independent variables (Age Group, Ethnicity, School Type, and Device Use) because they had more than two nominal categories to be compared. The results of the MLR analyses have been presented separately under each component.

\section{Perception of Quality}

The participants' responses in the items related to perceptions on the Quality (Q1-Q7) (Tabel 5) showed that they were almost neutral $($ Mean $=3.07$, Standard Deviation $=0.71)$ to the overall quality of the ODL. That means, the graduate students the ODL program could not make their opinion either as good or bad about the program. Their opinion about the quality of assessment, motivation to adopt ICT, and availability of competent teachers was not significantly different from the neutral value 3 . They rated higher in the items related to quality of learning in the ODL and classes on online mode equally effective as the face-to-face classes. However, they rated low (below neutral) for the unavailability of digital educational resources as one of the difficulties in the ODL (Table 5 and Figure 2). 
Table 5. Descriptive Statistics and One-Sample t-test for the Perception of Quality of ODL

\begin{tabular}{lcrrrrr}
\hline \multicolumn{7}{c}{ One-Sample Statistics and t-Test (test value = 3) } \\
\hline Items & $\mathrm{N}$ & Mean & STD Dev & Mean Diff & t-Value & Sig. (two-tailed) \\
\hline Q1 & 71 & 3.23 & .959 & .225 & 1.980 & .052 \\
Q2 & 71 & 3.17 & 1.082 & .169 & 1.316 & .192 \\
Q3 & 71 & 3.14 & .930 & .141 & 1.276 & .206 \\
Q4 & 71 & 3.39 & .933 & .394 & 3.561 & .001 \\
Q5 & 71 & 2.96 & 1.088 & -.042 & -.327 & .744 \\
Q6 & 71 & 2.08 & .996 & -.915 & -7.742 & .000 \\
Q7 & 71 & 3.52 & 1.157 & .521 & 3.795 & .000 \\
\hline
\end{tabular}

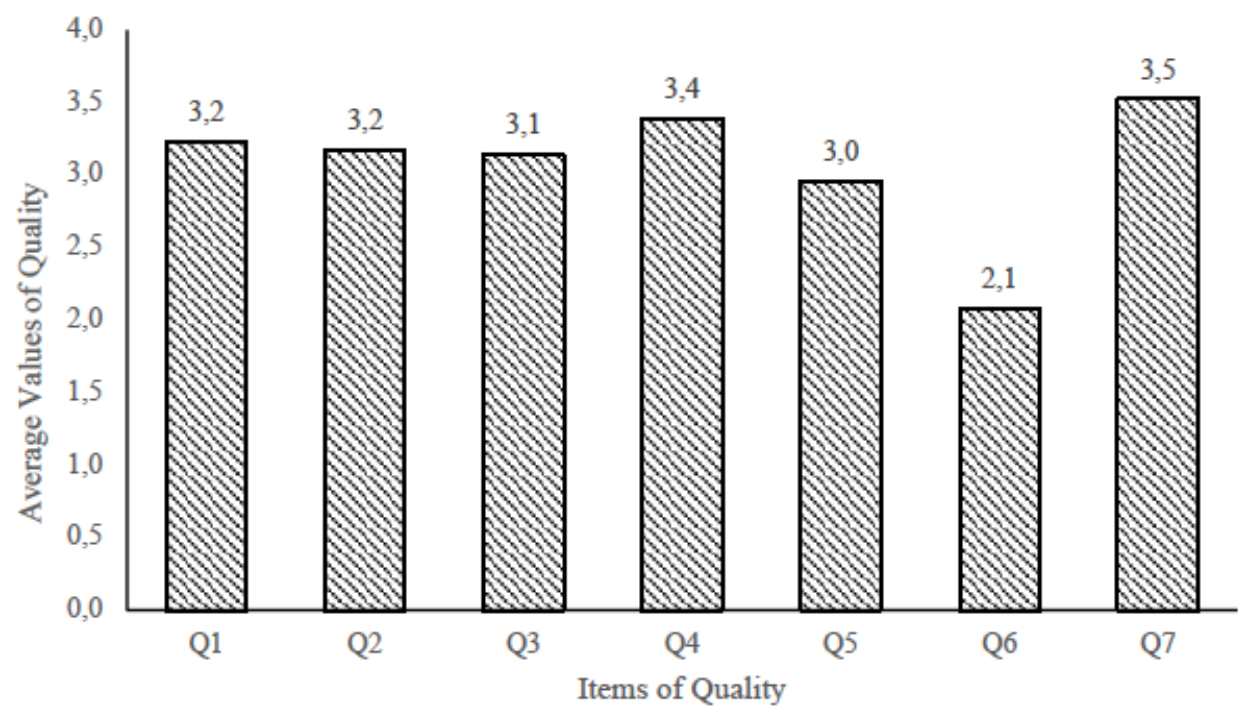

Figure 2. Average Value on Perception of Quality of the ODL

Independent-samples Man-Whitney U Test for the distribution of participants' perceptions on Quality of the ODL experience across the Gender (male and female) showed no significant difference (Retain Q- $\mathrm{H}_{0} 1$ ) at 0.05 level of significance. However, it was significant across Hometown (Reject $\left.\mathrm{Q}-\mathrm{H}_{0} 2\right)$ (Table 6). Likewise, the Kruskal-Wallis Test results in Table 6 showed no significant difference in the participants' perceptions across Age Groups, Ethnicity, School Type, and Device Use (Retain Q- $\left.\mathrm{H}_{0} 3, \mathrm{QH}_{0} 4, \mathrm{Q}-\mathrm{H}_{0} 5, \mathrm{QH}_{0} 6\right)$ ( $\left.\mathrm{p}>0.05\right)$.

Table 6. Hypothesis Test on the Distribution of Perception of Quality across Gender, Hometown, Age Group, Ethnicity, School Type, and Device Use

\begin{tabular}{|c|c|c|c|c|}
\hline \multicolumn{2}{|r|}{ Null Hypothesis } & \multirow[t]{2}{*}{ Test } & \multirow[t]{2}{*}{ Sig. } & \multirow[t]{2}{*}{ Decision } \\
\hline Hyp. No. & Hypothesis & & & \\
\hline $\mathrm{Q}-\mathrm{H}_{0} 1$ & $\begin{array}{l}\text { The distribution of Quality is the same } \\
\text { across categories of Gender. }\end{array}$ & $\begin{array}{l}\text { Independent-Samples } \\
\text { Mann-Whitney U Test }\end{array}$ & 0.533 & $\begin{array}{l}\text { Retain the null } \\
\text { hypothesis. }\end{array}$ \\
\hline $\mathrm{Q}-\mathrm{H}_{0} 2$ & $\begin{array}{l}\text { The distribution of Quality is the same } \\
\text { across categories of Hometown. }\end{array}$ & $\begin{array}{l}\text { Independent-Samples } \\
\text { Mann-Whitney U Test }\end{array}$ & 0.018 & $\begin{array}{l}\text { Reject the null } \\
\text { hypothesis. }\end{array}$ \\
\hline $\mathrm{Q}-\mathrm{H}_{0} 3$ & $\begin{array}{l}\text { The distribution of Quality is the same } \\
\text { across categories of Age Group. }\end{array}$ & $\begin{array}{l}\text { Independent-Samples } \\
\text { Kruskal-Wallis Test }\end{array}$ & 0.300 & $\begin{array}{l}\text { Retain the null } \\
\text { hypothesis. }\end{array}$ \\
\hline $\mathrm{Q}-\mathrm{H}_{0} 4$ & $\begin{array}{l}\text { The distribution of Quality is the same } \\
\text { across categories of Ethnicity. }\end{array}$ & $\begin{array}{l}\text { Independent-Samples } \\
\text { Kruskal-Wallis Test }\end{array}$ & 0.052 & $\begin{array}{l}\text { Retain the null } \\
\text { hypothesis. }\end{array}$ \\
\hline $\mathrm{Q}-\mathrm{H}_{0} 5$ & $\begin{array}{l}\text { The distribution of Quality is the same } \\
\text { across categories of Type of School. }\end{array}$ & $\begin{array}{l}\text { Independent-Samples } \\
\text { Kruskal-Wallis Test }\end{array}$ & 0.146 & $\begin{array}{l}\text { Retain the null } \\
\text { hypothesis. }\end{array}$ \\
\hline $\mathrm{Q}-\mathrm{H}_{0} 6$ & $\begin{array}{l}\text { The distribution of Quality is the same } \\
\text { across categories of Device Use. }\end{array}$ & $\begin{array}{l}\text { Independent-Samples } \\
\text { Kruskal-Wallis Test }\end{array}$ & 0.798 & $\begin{array}{l}\text { Retain the null } \\
\text { hypothesis. }\end{array}$ \\
\hline
\end{tabular}

Asymptotic significances are displayed at the level of 0.05 . 
An MLR analysis was run for the dependent variable Quality and the independent variables (Gender, Location, Ethnicity, Age Group, School Type, Device Use, and perceptions on Opportunity, Relevance, Development, Support, and Challenges) (Table 7). The results showed that Age Group (Age 2), Ethnicity (Brahman), School Type (Community), and perception (Support and Challenges) were the significant predictors of participants' views on the Quality of the ODL (the significant values being 0.015, 0.009, 0.016, 0.000, and 0.007 , respectively, with $R^{2}$ of regression $=0.643$ and variance being significant at $\left.p<0.05\right)$. None of the other independent variables were significant predictors of the participants' opinions on the Quality of the ODL program ( $p>0.05)$. Four independent variables (Age3, Baishya, MobAndLap, and InsSchool) were automatically excluded from the model by the SPSS because their tolerance values were all zeros making the variance inflation factor (VIF) infinitely large due to the existence of multiple collinearities caused by those variables.

Table 7. MLR Analysis of Dependent Variable Quality and Independent Variables (Gender, Location, Ethnicity, Age Group, School Type, Device Use and Perceptions of Opportunity, Relevance, Development,

Support, and Challenges)

\begin{tabular}{|c|c|c|c|c|c|c|c|c|}
\hline \multirow[t]{2}{*}{ Model } & \multirow[t]{2}{*}{$\begin{array}{l}\text { Model } \\
\text { Parameters }\end{array}$} & \multicolumn{2}{|l|}{$\begin{array}{l}\text { Unstandardized } \\
\text { Coefficients }\end{array}$} & \multicolumn{3}{|l|}{$\begin{array}{l}\text { Standardized } \\
\text { Coefficients }\end{array}$} & \multicolumn{2}{|c|}{$\begin{array}{l}\text { Collinearity } \\
\text { Statistics }\end{array}$} \\
\hline & & B & $\begin{array}{l}\text { Std. } \\
\text { Error }\end{array}$ & Beta & $\mathrm{t}$ & Sig. & Tolerance & VIF \\
\hline \multirow[t]{5}{*}{1} & (Constant) & 2.717 & .987 & & 2.753 & .008 & & \\
\hline & Gender & -.451 & .248 & -.256 & -1.821 & .074 & .356 & 2.806 \\
\hline & Hometown & -.269 & .165 & -.191 & -1.628 & .110 & .512 & 1.954 \\
\hline & Age2 & -.485 & .192 & -.282 & -2.528 & .015 & .564 & 1.774 \\
\hline & Age4 & .010 & .182 & .005 & .056 & .955 & .743 & 1.346 \\
\hline \multirow{4}{*}{$\begin{array}{l}F(18,52)= \\
5.014, p<0.05 \\
R^{2}=0.634\end{array}$} & Age5 & -.110 & .498 & -.026 & -.220 & .826 & .511 & 1.957 \\
\hline & Brahman & .443 & .163 & .316 & 2.719 & .009 & .521 & 1.918 \\
\hline & Kshetree & .094 & .187 & .055 & .503 & .617 & .593 & 1.685 \\
\hline & Laptop & .322 & .163 & .210 & 1.974 & .054 & .623 & 1.606 \\
\hline \multirow{4}{*}{$\begin{array}{l}\text { Excluded: } \\
\text { Age3, Baishya, } \\
\text { Mob. and } \\
\text { Laptop, Ins. } \\
\text { School }\end{array}$} & $\begin{array}{l}\text { Mobile } \\
\text { Phone }\end{array}$ & -.020 & .303 & -.006 & -.065 & .948 & .707 & 1.414 \\
\hline & Desktop & .156 & .441 & .037 & .355 & .724 & .652 & 1.534 \\
\hline & Com. School & .412 & .166 & .245 & 2.489 & .016 & .723 & 1.383 \\
\hline & Pub. School & .139 & .175 & .089 & .796 & .430 & .559 & 1.791 \\
\hline \multirow{6}{*}{ (0 tolerance) } & Other School & -.281 & .301 & -.120 & -.933 & .355 & .429 & 2.333 \\
\hline & Opportunity & .184 & .144 & .147 & 1.278 & .207 & .530 & 1.888 \\
\hline & Relevance & -.205 & .178 & -.151 & -1.156 & .253 & .410 & 2.441 \\
\hline & Development & .052 & .147 & .043 & .354 & .725 & .479 & 2.087 \\
\hline & Support & .424 & .107 & .432 & 3.968 & .000 & .592 & 1.688 \\
\hline & Challenges & -.250 & .089 & -.261 & -2.816 & .007 & .817 & 1.225 \\
\hline
\end{tabular}

Dependent Variable: Quality

\section{Perception of Opportunity}

The participant responses in the items related to the perception of the educational Opportunity through the ODL showed that they were very positive $($ Mean $=4.14$, Standard Deviation $=0.52)$ to the educational opportunity through the ODL. This means that the graduate students in the ODL had a high-level feeling that the program provided them an opportunity for higher education which, otherwise, would not be possible for them without leaving their jobs. Their opinion about the course content, process, and context; comfort of education, curriculum, interactive environment, flexibility, and scope of distance education all were rated significantly above the neutral value (Table 8 and Figure 3 ). 
Table 8. Descriptive Statistics and One-Sample t-test for the Perception of Educational Opportunity through ODL

\begin{tabular}{lcrrrrr}
\hline \multicolumn{7}{c}{ One-Sample Statistics and Test at Population Mean = } \\
\hline Items & $\mathrm{N}$ & Mean & STD Dev & Mean Diff & t-Value & Sig. (two-tailed) \\
\hline O1 & 71 & 4.00 & .697 & 1.000 & 12.090 & .000 \\
O2 & 71 & 4.27 & .861 & 1.268 & 12.403 & .000 \\
O3 & 71 & 3.54 & 1.053 & .535 & 4.282 & .000 \\
O4 & 71 & 4.11 & .854 & 1.113 & 10.973 & .000 \\
O5 & 71 & 3.54 & .969 & .535 & 4.656 & .000 \\
O6 & 71 & 4.01 & .870 & 1.014 & 9.821 & .000 \\
O7 & 71 & 4.32 & .752 & 1.324 & 14.842 & .000 \\
\hline
\end{tabular}

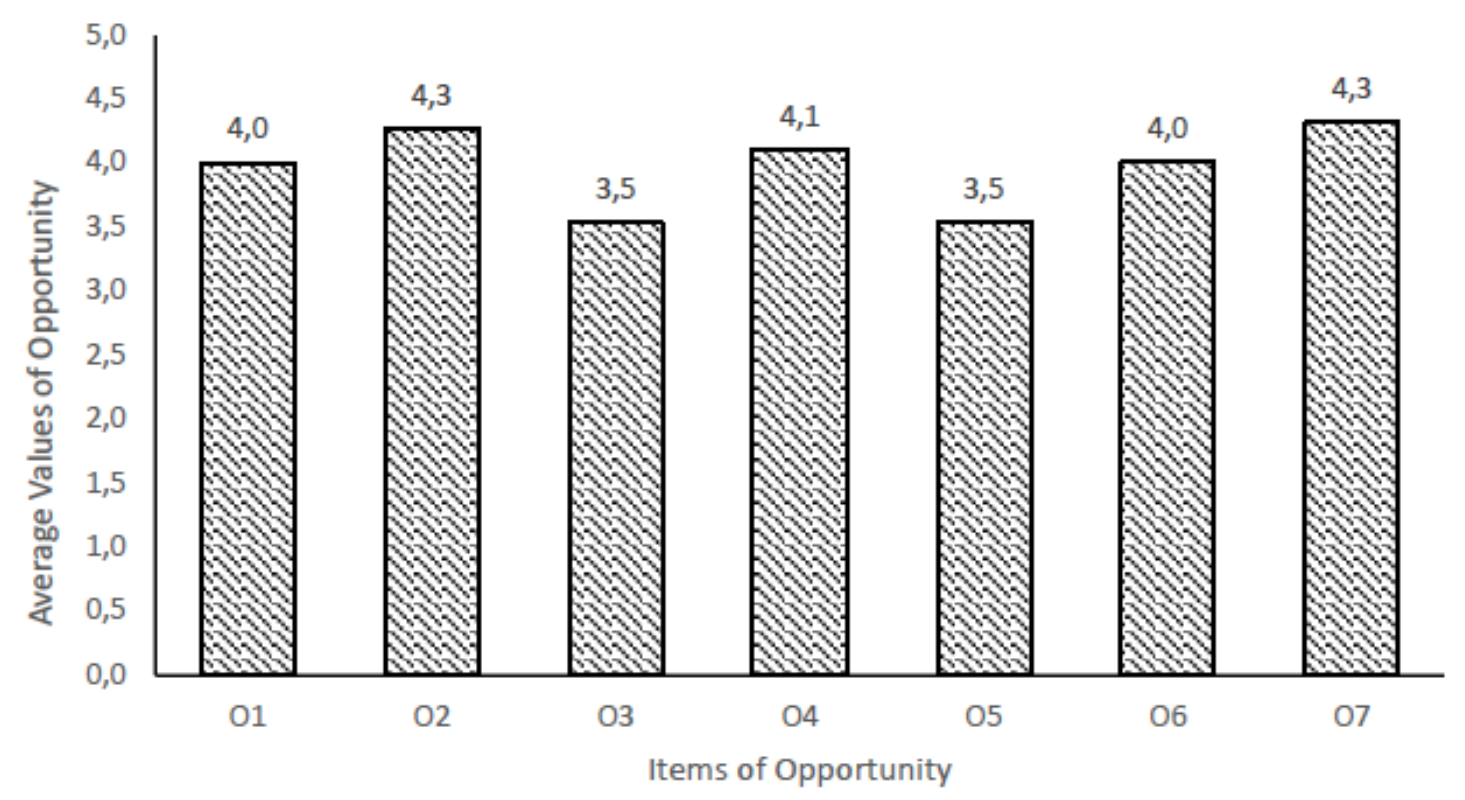

Figure 3. Average Value of Perception of Educational Opportunity through the ODL

Independent-samples Man-Whitney U Test for the distribution of participants' perceptions on educational Opportunity through the ODL across the Gender (male and female) showed no significant difference (Retain $\left.\mathrm{O}-\mathrm{H}_{0} 1\right)$ at 0.05 level of significance. However, it was significantly different across the Hometown (Reject

O-H 2 ) (Table 9). Likewise, the Kruskal-Wallis Test results in Table 9 showed no significant difference in the participants' perceptions of educational Opportunity through the ODL across Age Groups, Ethnicity, School Type, and Device Use (Retain $\left.\mathrm{O}_{-} \mathrm{H}_{0} 3, \mathrm{O}-\mathrm{H}_{0} 4, \mathrm{O}-\mathrm{H}_{0} 5, \mathrm{O}-\mathrm{H}_{0} 6\right)(\mathrm{p}>0.05)$.

Table 9. Hypothesis Test on the Distribution of Perception of Educational Opportunity across Gender, Hometown, Age Group, Ethnicity, School Type, and Device Use

\begin{tabular}{|c|c|c|c|c|}
\hline \multicolumn{2}{|r|}{ Null Hypothesis } & \multirow[t]{2}{*}{ Test } & \multirow[t]{2}{*}{ Sig. } & \multirow[t]{2}{*}{ Decision } \\
\hline Hyp. No. & Hypothesis & & & \\
\hline $\mathrm{O}-\mathrm{H}_{0} 1$ & $\begin{array}{l}\text { The distribution of Opportunity is the same } \\
\text { across categories of Gender. }\end{array}$ & $\begin{array}{l}\text { Independent- } \\
\text { Samples Mann- } \\
\text { Whitney U Test }\end{array}$ & 0.711 & $\begin{array}{l}\text { Retain the null } \\
\text { hypothesis. }\end{array}$ \\
\hline $\mathrm{O}-\mathrm{H}_{0} 2$ & $\begin{array}{l}\text { The distribution of Opportunity is the same } \\
\text { across categories of Hometown. }\end{array}$ & $\begin{array}{l}\text { Independent- } \\
\text { Samples Mann- } \\
\text { Whitney U Test }\end{array}$ & 0.022 & $\begin{array}{l}\text { Reject the null } \\
\text { hypothesis. }\end{array}$ \\
\hline
\end{tabular}




\begin{tabular}{|c|c|c|c|c|}
\hline $\mathrm{O}-\mathrm{H}_{0} 3$ & $\begin{array}{l}\text { The distribution of Opportunity is the same } \\
\text { across categories of Age Group. }\end{array}$ & $\begin{array}{l}\text { Independent- } \\
\text { Samples Kruskal- } \\
\text { Wallis Test }\end{array}$ & 0.425 & $\begin{array}{l}\text { Retain the null } \\
\text { hypothesis. }\end{array}$ \\
\hline $\mathrm{O}-\mathrm{H}_{0} 4$ & $\begin{array}{l}\text { The distribution of Opportunity is the same } \\
\text { across categories of Ethnicity. }\end{array}$ & $\begin{array}{l}\text { Independent- } \\
\text { Samples Kruskal- } \\
\text { Wallis Test }\end{array}$ & 0.541 & $\begin{array}{l}\text { Retain the null } \\
\text { hypothesis. }\end{array}$ \\
\hline $\mathrm{O}-\mathrm{H}_{0} 5$ & $\begin{array}{l}\text { The distribution of Opportunity is the same } \\
\text { across categories of Type of School. }\end{array}$ & $\begin{array}{l}\text { Independent- } \\
\text { Samples Kruskal- } \\
\text { Wallis Test }\end{array}$ & 0.976 & $\begin{array}{l}\text { Retain the null } \\
\text { hypothesis. }\end{array}$ \\
\hline $\mathrm{O}-\mathrm{H}_{0} 6$ & $\begin{array}{l}\text { The distribution of Opportunity is the same } \\
\text { across categories of Device Use. }\end{array}$ & $\begin{array}{l}\text { Independent- } \\
\text { Samples Kruskal- } \\
\text { Wallis Test }\end{array}$ & 0.298 & $\begin{array}{l}\text { Retain the null } \\
\text { hypothesis. }\end{array}$ \\
\hline
\end{tabular}

Asymptotic significances are displayed at the level of 0.05 .

An MLR analysis of dependent variable Opportunity and independent variables (Gender, Location, Ethnicity, Age Group, School Type, Device Use, and perceptions on Relevance, Development, Support, and Challenges was performed (Table 10). The results showed that only Relevancy was the significant predictors of participants' views on the Opportunity of the ODL (the significant values being 0.001 , with $\mathrm{R}^{2}$ of regression $=0.487$ and variance being significant at $\mathrm{p}<0.05$ ). None of the other independent variables were significant predictors of the participants' opinions on their learning Opportunity in the ODL program at $\mathrm{p}>0.05$. Four independent variables (Age2, Brahman, MobAndLap, and InsSchool) were excluded from the model because their tolerance values were all zeros making the variance inflation factor (VIF) infinitely large as a result of multiple collinearities with those variables (Table 10).

Table 10. MLR Analysis of Dependent Variable Opportunity and Independent Variables (Gender, Location, Ethnicity, Age Group, School Type, Device Use and Perceptions of Quality, Relevance, Development, Support, and Challenges)

\begin{tabular}{|c|c|c|c|c|c|c|c|c|}
\hline \multirow[t]{2}{*}{ Model } & \multirow[t]{2}{*}{$\begin{array}{l}\text { Model Parame- } \\
\text { ters }\end{array}$} & \multicolumn{2}{|l|}{$\begin{array}{l}\text { Unstandar- } \\
\text { dized Coeffi- } \\
\text { cients }\end{array}$} & \multicolumn{3}{|l|}{$\begin{array}{l}\text { Standardi- } \\
\text { zed Coeffi- } \\
\text { cients }\end{array}$} & \multicolumn{2}{|c|}{$\begin{array}{l}\text { Collinearity Statis- } \\
\text { tics }\end{array}$} \\
\hline & & B & Std. Error & Beta & $\mathrm{t}$ & Sig. & Tolerance & VIF \\
\hline \multirow[t]{6}{*}{2} & (Constant) & -.293 & .973 & & -.301 & .765 & & \\
\hline & Gender & .313 & .239 & .221 & 1.310 & .196 & .346 & 2.890 \\
\hline & Hometown & .084 & .161 & .074 & .524 & .602 & .489 & 2.043 \\
\hline & Age3 & -.001 & .193 & -.001 & -.005 & .996 & .346 & 2.888 \\
\hline & Age4 & .032 & .242 & .021 & .132 & .896 & .381 & 2.627 \\
\hline & Age 5 & .404 & .451 & .119 & .896 & .374 & .561 & 1.783 \\
\hline \multirow{5}{*}{$\begin{array}{l}F(18,52)= \\
2.737, p< \\
0.05, R^{2}= \\
0.487\end{array}$} & Kshetree & .139 & .166 & .101 & .838 & .406 & .681 & 1.469 \\
\hline & Baishya & .106 & .165 & .086 & .645 & .522 & .552 & 1.811 \\
\hline & Laptop & -.052 & .161 & -.042 & -.323 & .748 & .580 & 1.723 \\
\hline & Mobile Phone & -.247 & .286 & -.101 & -.864 & .392 & .717 & 1.394 \\
\hline & Desktop & -.240 & .418 & -.070 & -.574 & .569 & .654 & 1.528 \\
\hline \multirow{4}{*}{$\begin{array}{l}\text { Excluded: } \\
\text { Age2, Brah- } \\
\text { man, Mob. } \\
\text { And Laptop, } \\
\text { Ins. School }\end{array}$} & Com. School & .002 & .166 & .002 & .013 & .990 & .646 & 1.548 \\
\hline & Pub. School & .146 & .166 & .117 & .882 & .382 & .560 & 1.786 \\
\hline & Other School & .329 & .285 & .175 & 1.155 & .253 & .432 & 2.313 \\
\hline & Relevance & .530 & .154 & .488 & 3.438 & .001 & .490 & 2.040 \\
\hline \multirow[t]{4}{*}{ (0 tolerance) } & Development & .116 & .139 & .119 & .833 & .409 & .484 & 2.065 \\
\hline & Support & .160 & .114 & .204 & 1.410 & .164 & .472 & 2.119 \\
\hline & Challenges & .051 & .090 & .067 & .568 & .573 & .713 & 1.403 \\
\hline & Quality & .166 & .130 & .207 & 1.278 & .207 & .377 & 2.652 \\
\hline
\end{tabular}

Dependent Variable: Opportunity 


\section{Perception of Relevance}

The participant responses to the items related to the Relevance of the ODL showed that they were positive (Mean $=3.94$ and Standard Deviation $=0.57$ ) to the relevancy of the ODL in Nepal. That means the graduate students in the ODL program found the program relevant to their needs for professional growth and development. Their opinion about the ODL program in Nepal for higher education, ICT tools for learning, effective and timely classes, connectivity and delivery of lessons, professional growth, and access to higher education seemed to prove it very relevant in the current context of COVID-19 pandemic (Table 11 and Figure 4).

Table 11. Descriptive Statistics and One-Sample t-Test for the Perception of Educational Relevance of ODL

\begin{tabular}{lcccrrr}
\hline \multicolumn{7}{c}{ One-Sample Statistics and Test at Population Mean = 3 } \\
\hline Items & $\mathrm{N}$ & Mean & STD Dev & Mean Diff & t-Value & Sig. (two-tailed) \\
\hline R1 & 71 & 4.14 & .850 & 1.141 & 11.307 & .000 \\
R2 & 71 & 4.24 & .686 & 1.239 & 15.227 & .000 \\
R3 & 71 & 4.10 & .740 & 1.099 & 12.513 & .000 \\
R4 & 71 & 3.89 & .871 & .887 & 8.585 & .000 \\
R5 & 71 & 4.11 & .854 & 1.113 & 10.973 & .000 \\
R6 & 71 & 4.20 & .729 & 1.197 & 13.830 & .000 \\
\hline
\end{tabular}

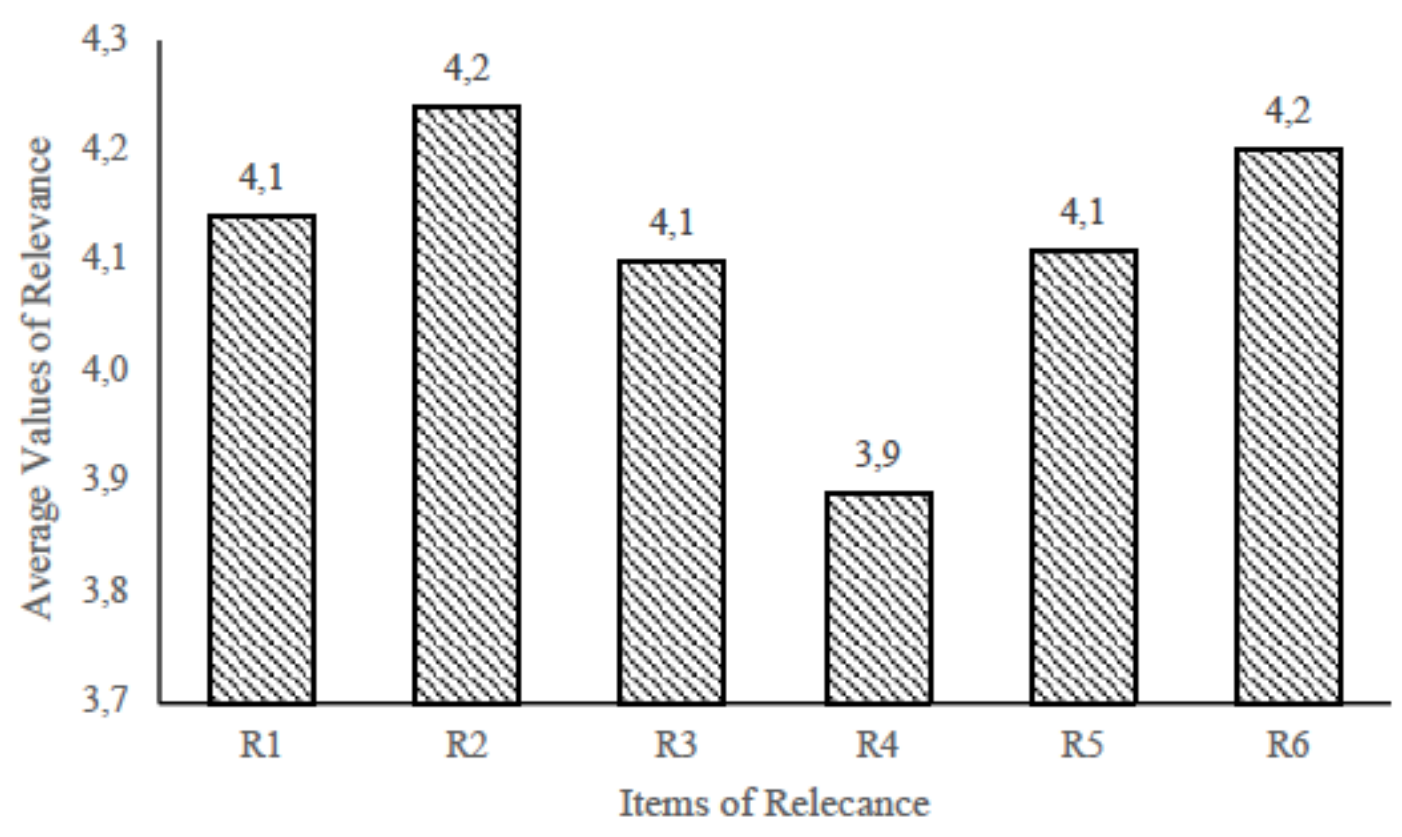

Figure 4. Average Value on Perception of Educational Relevance of the ODL 
Independent-samples Man-Whitney U Test for the distribution of participants' perceptions of educational Relevancy of the ODL across the Gender (male and female) showed no significant difference (Retain $\mathrm{R}-\mathrm{H}_{0} 1$ ) at 0.05 level of significance. However, it was significantly different across the Hometown (Reject R- $\mathrm{H}_{0} 2$ ) (Table

12). Likewise, the Kruskal-Wallis Test results in Table 12 showed no significant difference in the participants' perceptions of educational Relevancy of the ODL across Age Groups, Ethnicity, and School Type (Retain $\left.\mathrm{R}-\mathrm{H}_{0} 3, \mathrm{R}-\mathrm{H}_{0} 4, \mathrm{R}-\mathrm{H}_{0} 5\right)$, but the participants' groups differed significantly in their opinion based on the Device Use $\left(\right.$ Reject $\left.\mathrm{R}^{-\mathrm{H}_{0}} \mathrm{6}\right)(\mathrm{p}<0.05)$. The post-hoc test for the comparison of the groups with device usage showed that the students' using laptop differed signficantly with those using mobile phone to access ODL classes and materials at 0.05 level of signficance. This difference in the perceptions of Relevance in these two groups might be due to their different experience in these devices to make the ODL relevant or not.

Table 12. Hypothesis Test on the Distribution of Perception of Educational Relevance of ODL across Gender, Hometown, Age Group, Ethnicity, School Type, and Device Use

\begin{tabular}{|c|c|c|c|c|}
\hline \multicolumn{2}{|r|}{ Null Hypothesis } & \multirow[t]{2}{*}{ Test } & \multirow[t]{2}{*}{ Sig. } & \multirow[t]{2}{*}{ Decision } \\
\hline Hyp. No. & Hypothesis & & & \\
\hline $\mathrm{R}-\mathrm{H}_{0} 1$ & $\begin{array}{l}\text { The distribution of Relevance is the } \\
\text { same across categories of Gender. }\end{array}$ & $\begin{array}{l}\text { Independent-Samples } \\
\text { Mann-Whitney U Test }\end{array}$ & 0.930 & $\begin{array}{l}\text { Retain the null } \\
\text { hypothesis. }\end{array}$ \\
\hline $\mathrm{R}-\mathrm{H}_{0} 2$ & $\begin{array}{l}\text { The distribution of Relevance is the } \\
\text { same across categories of Hometown. }\end{array}$ & $\begin{array}{l}\text { Independent-Samples } \\
\text { Mann-Whitney U Test }\end{array}$ & 0.018 & $\begin{array}{l}\text { Reject the null } \\
\text { hypothesis. }\end{array}$ \\
\hline $\mathrm{R}-\mathrm{H}_{0} 3$ & $\begin{array}{l}\text { The distribution of Relevance is the } \\
\text { same across categories of Age Group. }\end{array}$ & $\begin{array}{l}\text { Independent-Samples } \\
\text { Kruskal-Wallis Test }\end{array}$ & 0.441 & $\begin{array}{l}\text { Retain the null } \\
\text { hypothesis. }\end{array}$ \\
\hline $\mathrm{R}-\mathrm{H}_{0} 4$ & $\begin{array}{l}\text { The distribution of Relevance is the } \\
\text { same across categories of Ethnicity. }\end{array}$ & $\begin{array}{l}\text { Independent-Samples } \\
\text { Kruskal-Wallis Test }\end{array}$ & 0.371 & $\begin{array}{l}\text { Retain the null } \\
\text { hypothesis. }\end{array}$ \\
\hline $\mathrm{R}-\mathrm{H}_{0} 5$ & $\begin{array}{l}\text { The distribution of Relevance is the same } \\
\text { across categories of Type of School. }\end{array}$ & $\begin{array}{l}\text { Independent-Samples } \\
\text { Kruskal-Wallis Test }\end{array}$ & 0.466 & $\begin{array}{l}\text { Retain the null } \\
\text { hypothesis. }\end{array}$ \\
\hline $\mathrm{R}-\mathrm{H}_{0} 6$ & $\begin{array}{l}\text { The distribution of Relevance is the } \\
\text { same across categories of Device Use. }\end{array}$ & $\begin{array}{l}\text { Independent-Samples } \\
\text { Kruskal-Wallis Test }\end{array}$ & 0.030 & $\begin{array}{l}\text { Reject the null } \\
\text { hypothesis. }\end{array}$ \\
\hline
\end{tabular}

Asymptotic significances are displayed at the level of 0.05 .

The MLR analysis of dependent variable Relevancy and independent variables (Gender, Hometown, Ethnicity, Age Group, School Type (Institutional), Device Use, and perceptions on Quality, Opportunity, Development, Support, and Challenges) is presented in Table 13. The results showed that Gender, Hometown, Use of Device (Laptop), School Type (Other School), and perception (Development and Opportunity) were the significant predictors of participants' views on the Relevancy of the ODL (the significant values being $0.016,0.004,0.006,0.007,0.041$ and 0.001 , respectively, with $\mathrm{R}^{2}$ of regression $=0.601$ and variance being significant at $\mathrm{p}<0.05$. None of the other independent variables were significant predictors of the participants' opinions on their learning Relevancy in the ODL program at $\mathrm{p}>0.05$. Four independent variables (Age3, Baishya, MobAndLap, and InsSchool) were excluded from the model because their tolerance values were all zeros making the variance inflation factor (VIF) infinitely large due to the potential existence of multiple collinearities among those variables (Table 13). 
Table 13. MLR Analysis of Dependent Variable Relevance and Independent Variables (Gender, Location, Ethnicity, Age Group, School Type, Device Use and Perceptions of Quality, Relevance, Development, Support, and Challenges)

\begin{tabular}{|c|c|c|c|c|c|c|c|c|}
\hline \multirow[t]{2}{*}{ Model } & \multirow[t]{2}{*}{$\begin{array}{l}\text { Model } \\
\text { Parameters }\end{array}$} & \multicolumn{2}{|l|}{$\begin{array}{l}\text { Unstandardized } \\
\text { Coefficients }\end{array}$} & \multicolumn{3}{|l|}{$\begin{array}{l}\text { Standardized } \\
\text { Coefficients }\end{array}$} & \multicolumn{2}{|l|}{$\begin{array}{l}\text { Collinearity } \\
\text { Statistics }\end{array}$} \\
\hline & & $B$ & $\begin{array}{l}\text { Std. } \\
\text { Error }\end{array}$ & Beta & $\mathrm{t}$ & Sig. & Tolerance & VIF \\
\hline \multirow[t]{4}{*}{3} & (Constant) & 3.171 & .686 & & 4.625 & .000 & & \\
\hline & Gender & -.466 & .186 & -.358 & -2.502 & .016 & .375 & 2.665 \\
\hline & Hometown & -.361 & .121 & -.347 & -2.995 & .004 & .571 & 1.752 \\
\hline & Age2 & -.243 & .153 & -.191 & -1.583 & .120 & .526 & 1.900 \\
\hline \multirow{6}{*}{$\begin{array}{l}F(18,52)= \\
4.345, p< \\
0.05, R^{2}= \\
0.601\end{array}$} & Age4 & .040 & .140 & .029 & .286 & .776 & .744 & 1.344 \\
\hline & Age5 & -.175 & .383 & -.056 & -.457 & .650 & .512 & 1.951 \\
\hline & Brahman & .201 & .131 & .194 & 1.526 & .133 & .477 & 2.097 \\
\hline & Kshetree & .125 & .144 & .099 & .873 & .386 & .599 & 1.669 \\
\hline & Laptop & .346 & .122 & .305 & 2.843 & .006 & .669 & 1.494 \\
\hline & $\begin{array}{l}\text { Mobile } \\
\text { Phone }\end{array}$ & .056 & .234 & .025 & .240 & .811 & .708 & 1.413 \\
\hline \multirow{4}{*}{$\begin{array}{l}\text { Excluded: } \\
\text { Age3, Baishya, } \\
\text { Mob. And } \\
\text { Laptop, Ins. } \\
\text { School }\end{array}$} & Desktop & .116 & .340 & .037 & .343 & .733 & .652 & 1.534 \\
\hline & Com. School & -.023 & .135 & -.018 & -.167 & .868 & .646 & 1.547 \\
\hline & Pub. School & -.218 & .132 & -.189 & -1.647 & .106 & .581 & 1.722 \\
\hline & Other School & -.618 & .218 & -.356 & -2.831 & .007 & .487 & 2.055 \\
\hline \multirow{5}{*}{ ( 0 tolerance) } & Development & .229 & .109 & .256 & 2.099 & .041 & .518 & 1.929 \\
\hline & Support & -.095 & .093 & -.131 & -1.021 & .312 & .464 & 2.156 \\
\hline & Challenges & -.044 & .073 & -.062 & -.596 & .554 & .713 & 1.402 \\
\hline & Quality & -.122 & .106 & -.165 & -1.156 & .253 & .375 & 2.667 \\
\hline & Opportunity & .349 & .102 & .379 & 3.438 & .001 & .630 & 1.587 \\
\hline
\end{tabular}

Dependent Variable: Relevancy

\section{Perception of Development}

The participants were very positive about their Development through the ODL in Nepal. The overall perception of professional development through the ODL was positive (Mean $=4.00$ and Standard Deviation $=0.58$ ). That means the graduate students in the ODL program were positive about their learning experiences in terms of their professional development while they were full-time teachers and students at the same time. They seemed to agree on the opinion that the ODL program helps them in promoting quality of education, professional enhancement in teaching-learning, independent and self-learning, and interaction among students and teachers through the ODL facilities in Nepal (Table 14 and Figure 5).

Table 14. Descriptive Statistics and One-Sample t-Test for the Perception of Educational Development of ODL

\begin{tabular}{|c|c|c|c|c|c|c|}
\hline \multicolumn{7}{|c|}{ One-Sample Statistics and Test at Population Mean = 3} \\
\hline Items & $\mathrm{N}$ & Mean & STD Dev & Mean Diff & t-Value & Sig. (two-tailed) \\
\hline D1 & 71 & 4.00 & .894 & 1.000 & 9.421 & .000 \\
\hline D2 & 71 & 4.32 & .692 & 1.324 & 16.114 & .000 \\
\hline D3 & 71 & 3.99 & .727 & .986 & 11.429 & .000 \\
\hline D4 & 71 & 3.99 & .853 & .986 & 9.734 & .000 \\
\hline D5 & 71 & 3.70 & 1.020 & .704 & 5.819 & .000 \\
\hline
\end{tabular}




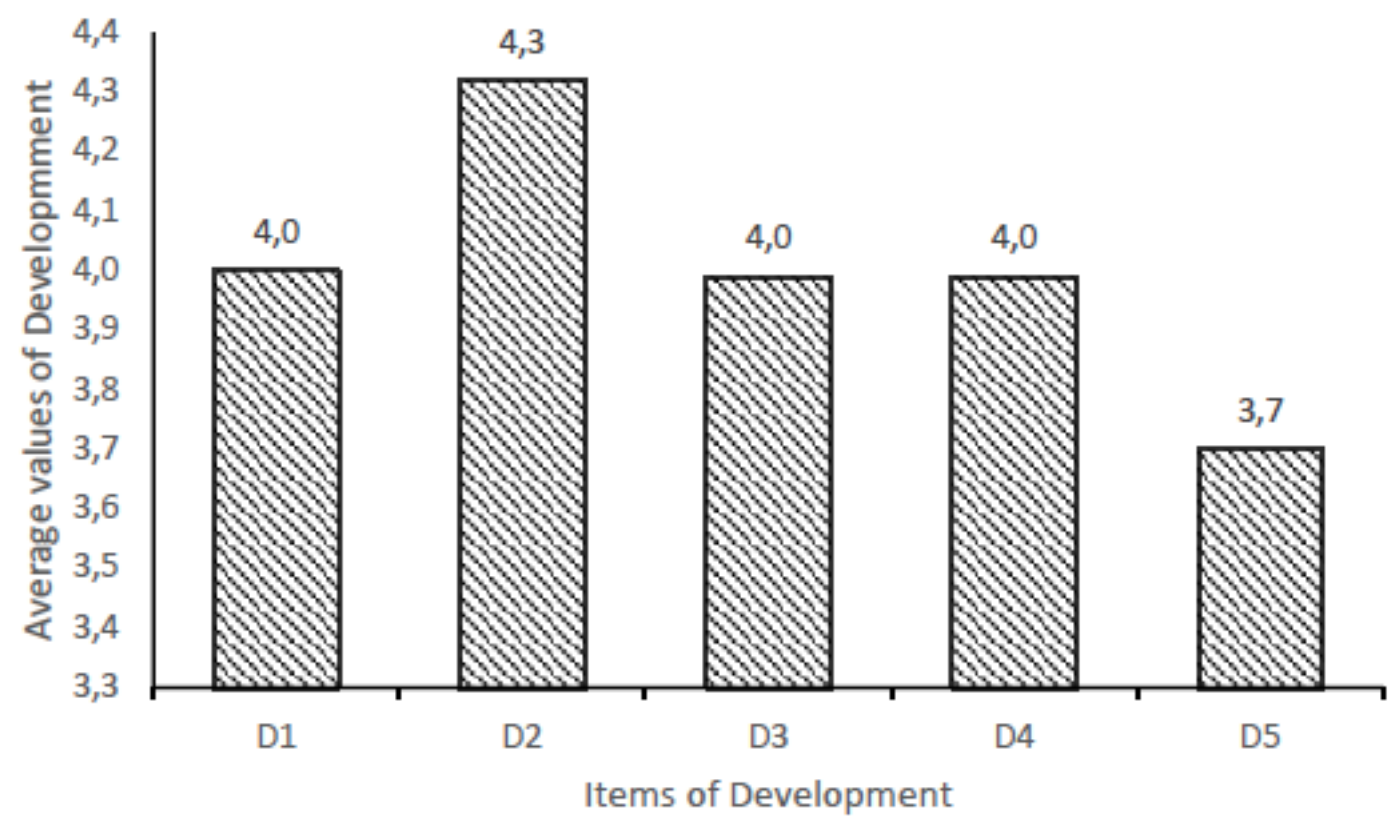

Figure 5. Average Value on Perception of Educational Development of the ODL

Independent-samples Man-Whitney U Test for the distribution of participants' perceptions on professional Development through the ODL across the Gender and Hometown showed no significant difference (Retain

D- $\mathrm{H}_{0} 1, \mathrm{D}-\mathrm{H}_{0} 2$ ) at 0.05 level of significance (Table 15). Likewise, the Kruskal-Wallis Test results in Table 15 showed no significant difference in the participants' perceptions of Development through the ODL across Age, Ethnicity, School Type, and Device Use (Retain D- $\left.\mathrm{H}_{0} 3, \mathrm{D}-\mathrm{H}_{0} 4, \mathrm{D}-\mathrm{H}_{0} 5, \mathrm{D}-\mathrm{H}_{0} 6\right)(\mathrm{p}<0.05)$.

Table 15. Hypothesis Test on the Distribution of Perception of academic Development through ODL across Gender, Hometown, Age Group, Ethnicity, School Type, and Device Use

\begin{tabular}{|c|c|c|c|c|}
\hline \multicolumn{2}{|r|}{ Null Hypothesis } & \multirow[t]{2}{*}{ Test } & \multirow[t]{2}{*}{ Sig. } & \multirow[t]{2}{*}{ Decision } \\
\hline Hyp. No. & Hypothesis & & & \\
\hline $\mathrm{D}-\mathrm{H}_{0} 1$ & $\begin{array}{l}\text { The distribution of student Development is } \\
\text { the same across categories of Gender. }\end{array}$ & $\begin{array}{l}\text { Independent-Samples } \\
\text { Mann-Whitney U Test }\end{array}$ & 0.532 & $\begin{array}{l}\text { Retain the null } \\
\text { hypothesis. }\end{array}$ \\
\hline $\mathrm{D}-\mathrm{H}_{0} 2$ & $\begin{array}{l}\text { The distribution of Development is the } \\
\text { same across categories of Hometown. }\end{array}$ & $\begin{array}{l}\text { Independent-Samples } \\
\text { Mann-Whitney U Test }\end{array}$ & 0.168 & $\begin{array}{l}\text { Retain the null } \\
\text { hypothesis. }\end{array}$ \\
\hline $\mathrm{D}-\mathrm{H}_{0} 3$ & $\begin{array}{l}\text { The distribution of Development is the } \\
\text { same across categories of Age Group. }\end{array}$ & $\begin{array}{l}\text { Independent-Samples } \\
\text { Kruskal-Wallis Test }\end{array}$ & 0.147 & $\begin{array}{l}\text { Retain the null } \\
\text { hypothesis. }\end{array}$ \\
\hline $\mathrm{D}-\mathrm{H}_{0} 4$ & $\begin{array}{l}\text { The distribution of Development is the } \\
\text { same across categories of Ethnicity. }\end{array}$ & $\begin{array}{l}\text { Independent-Samples } \\
\text { Kruskal-Wallis Test }\end{array}$ & 0.400 & $\begin{array}{l}\text { Retain the null } \\
\text { hypothesis. }\end{array}$ \\
\hline $\mathrm{D}-\mathrm{H}_{0} 5$ & $\begin{array}{l}\text { The distribution of Development is the } \\
\text { same across categories of Type of School. }\end{array}$ & $\begin{array}{l}\text { Independent-Samples } \\
\text { Kruskal-Wallis Test }\end{array}$ & 0.625 & $\begin{array}{l}\text { Retain the null } \\
\text { hypothesis. }\end{array}$ \\
\hline$D-H_{0} 6$ & $\begin{array}{l}\text { The distribution of Development is the } \\
\text { same across categories of Device Use. }\end{array}$ & $\begin{array}{l}\text { Independent-Samples } \\
\text { Kruskal-Wallis Test }\end{array}$ & 0.505 & $\begin{array}{l}\text { Retain the null } \\
\text { hypothesis. }\end{array}$ \\
\hline
\end{tabular}

Asymptotic significances are displayed at the level of 0.05 .

An MLR analysis was conducted between the dependent variable Development and the independent variables (Gender, Location, Ethnicity, Age Group, School Type, Device Use, and perceptions on Quality, Opportunity, Relevance, Support, and Challenges)). The results in Table 16 showed that Age Group (Age4, 40-above) and Relevancy were the significant predictors of participants' views on their development through the ODL with the corresponding significant values being 0.023 and 0.041 , respectively, with $\mathrm{R}^{2}$ of regression $=0.522$ and variance being significant at $\mathrm{p}<0.05)$. None of the other independent variables were significant 
predictors of the participants' opinions on their Development through the ODL program, as $\mathrm{p}>0.05$. Four independent variables (Age3, Brahman, MobAndLap, and InsSchool) were excluded from the model because their tolerance values were all zeros making the variance inflation factor (VIF) infinitely large due to the potential existence of multiple collinearities among those variables (Table 16).

Table 16. MLR Analysis of Dependent Variable Development and Independent Variables (Gender, Location, Ethnicity, Age Group, School Type, Device Use and Perceptions of Quality, Relevance, Opportunity, Support, and Challenges)

\begin{tabular}{|c|c|c|c|c|c|c|c|c|}
\hline \multirow[t]{2}{*}{ Model } & \multirow[t]{2}{*}{$\begin{array}{l}\text { Model Parame- } \\
\text { ters }\end{array}$} & \multicolumn{2}{|l|}{$\begin{array}{l}\text { Unstandar- } \\
\text { dized Coeffi- } \\
\text { cients }\end{array}$} & \multicolumn{3}{|l|}{$\begin{array}{l}\text { Standardized } \\
\text { Coefficients }\end{array}$} & \multicolumn{2}{|c|}{$\begin{array}{l}\text { Collinearity Statis- } \\
\text { tics }\end{array}$} \\
\hline & & B & $\begin{array}{l}\text { Std. } \\
\text { Error }\end{array}$ & Beta & $\mathrm{t}$ & Sig. & Tolerance & VIF \\
\hline \multirow[t]{5}{*}{4} & (Constant) & 2.037 & 1.012 & & 2.013 & .049 & & \\
\hline & Gender & -.443 & .232 & -.305 & -1.904 & .062 & .358 & 2.791 \\
\hline & Hometown & -.087 & .159 & -.075 & -.545 & .588 & .490 & 2.042 \\
\hline & Age2 & -.205 & .189 & -.145 & -1.086 & .283 & .513 & 1.947 \\
\hline & Age4 & -.092 & .171 & -.059 & -.536 & .595 & .747 & 1.339 \\
\hline \multirow{5}{*}{$\begin{array}{l}F(18,52)= \\
3.156, p<0.05 \\
R^{2}=0.522\end{array}$} & Age5 & -1.040 & .446 & -.298 & -2.334 & .023 & .564 & 1.773 \\
\hline & Kshetree & -.118 & .165 & -.084 & -.718 & .476 & .678 & 1.475 \\
\hline & Baishya & -.184 & .162 & -.145 & -1.136 & .261 & .561 & 1.782 \\
\hline & Laptop & .073 & .159 & .058 & .458 & .649 & .582 & 1.719 \\
\hline & Mobile Phone & .036 & .286 & .014 & .126 & .900 & .707 & 1.414 \\
\hline \multirow{4}{*}{$\begin{array}{l}\text { Excluded: } \\
\text { Age3, Brah- } \\
\text { man, Mob. and } \\
\text { Laptop, Ins. } \\
\text { School }\end{array}$} & Desktop & .086 & .415 & .024 & .206 & .837 & .651 & 1.537 \\
\hline & Com. School & .034 & .165 & .025 & .208 & .836 & .647 & 1.547 \\
\hline & Pub. School & .131 & .165 & .102 & .794 & .431 & .558 & 1.791 \\
\hline & Other School & -.536 & .276 & -.277 & -1.942 & .058 & .452 & 2.212 \\
\hline \multirow[t]{5}{*}{ (0 tolerance) } & Support & .171 & .112 & .212 & 1.528 & .133 & .475 & 2.105 \\
\hline & Challenges & -.001 & .090 & -.002 & -.014 & .989 & .709 & 1.411 \\
\hline & Quality & .046 & .130 & .056 & .354 & .725 & .366 & 2.729 \\
\hline & Opportunity & .114 & .136 & .111 & .833 & .409 & .520 & 1.922 \\
\hline & Relevance & .341 & .162 & .306 & 2.099 & .041 & .433 & 2.308 \\
\hline
\end{tabular}

Dependent Variable: Development

\section{Perception of Support}

The participant responses in the items related to the perception of the Support in the ODL showed that they were almost neutral (Mean $=3.02$ and Standard Deviation $=0.72$ ) to the overall rating of this construct. That means the graduate students in the program did not have a biased feeling of the ODL either as supportive or not supportive. They were undecided regarding the program support. Their opinion about the quality of assessment, motivation to adopt ICT, and the availability of competent teachers was not significantly different from the neutral value 3 . They rated higher in the items related to quality of the learning in the ODL and classes on online mode equally effective as the face-to-face classes. However, they rated low (below neutral) for the unavailability of digital educational resources as difficulty in the ODL (Table 17 and Figure 6). 
Table 17. Descriptive Statistics and One-Sample t-Test for the Perception of Student Support in ODL Courses

\begin{tabular}{lrrrrrr}
\hline \multicolumn{7}{c}{ One-Sample Statistics and Test at Population Mean = } \\
\hline Items & $\mathrm{N}$ & Mean & STD Dev & Mean Diff & t-Value & Sig. (two-tailed) \\
\hline S1 & 71 & 3.27 & .925 & .268 & 2.437 & .017 \\
S2 & 71 & 4.24 & .686 & 1.239 & 15.227 & .000 \\
S3 & 71 & 3.10 & 1.197 & .099 & .694 & .490 \\
S4 & 71 & 3.38 & .900 & .380 & 3.559 & .001 \\
S5 & 71 & 2.96 & 1.034 & -.042 & -.344 & .732 \\
\hline
\end{tabular}

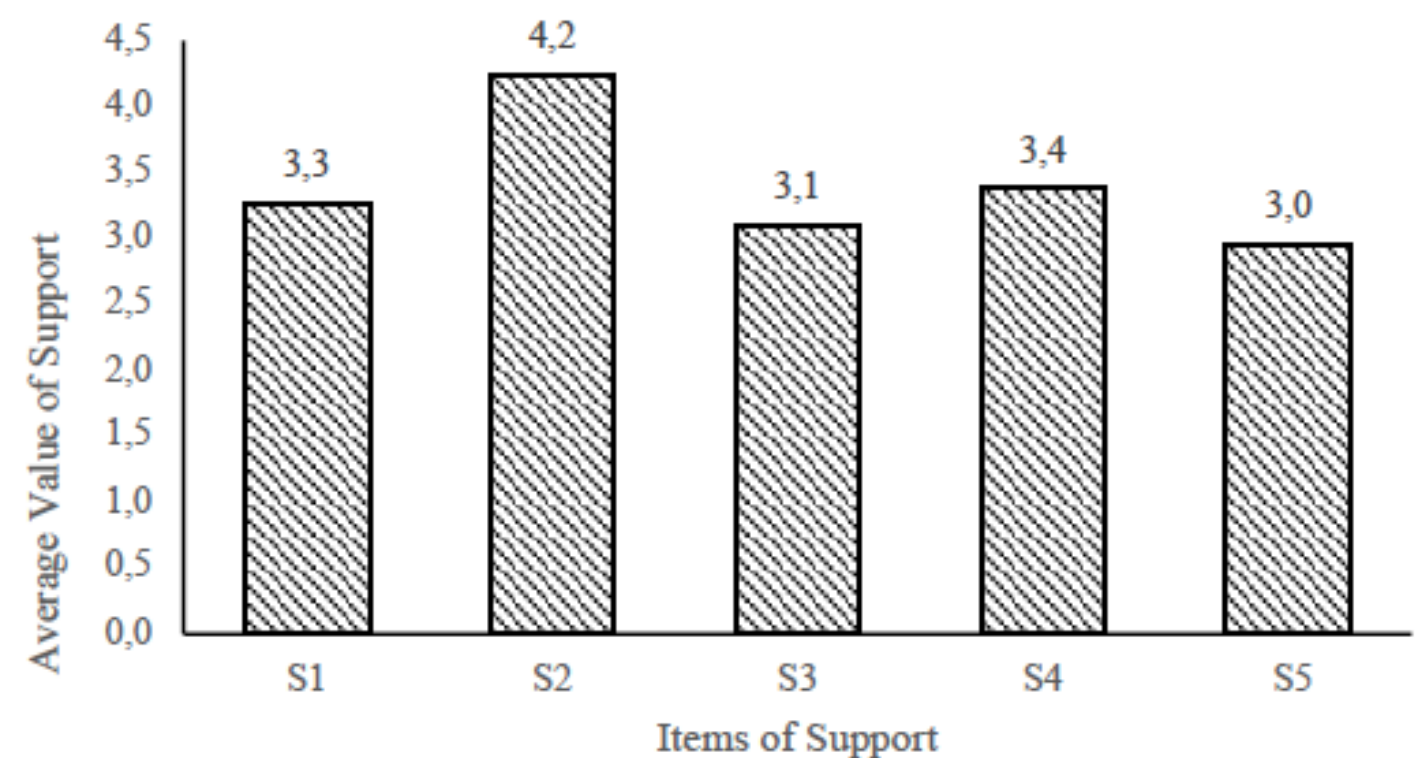

Figure 6. Average Value on Perception of Student Support in the ODL Courses

Independent-samples Man-Whitney U Test for the distribution of participants perceptions on student Challenges in the ODL courses across the Gender showed no significant difference (Retain S- $\mathrm{H}_{0} 1$ ), but the perceptual difference in Support was significant across their Hometown (Rejet S- $\mathrm{H}_{0} 2$ ) at 0.05 level of significance (Table 18). Likewise, the Kruskal-Wallis Test results in Table 18 showed no significant difference in the participants' perceptions of Support within the ODL across Age Groups, Ethnicity, School Type, and Device Use (Retain S-H 3 , S- $\left.\mathrm{H}_{0} 4, \mathrm{~S}-\mathrm{H}_{0} 5, \mathrm{~S}-\mathrm{H}_{0} 6\right)(\mathrm{p}<0.05)$.

Table 18. Hypothesis Test on the Distribution of Perception of Support in ODL Courses across Gender, Hometown, Age Group, Ethnicity, School Type, and Device Use

\begin{tabular}{|c|c|c|c|c|}
\hline \multicolumn{2}{|r|}{ Null Hypothesis } & \multirow[t]{2}{*}{ Test } & \multirow[t]{2}{*}{ Sig. } & \multirow[t]{2}{*}{ Decision } \\
\hline Hyp. No. & Hypothesis & & & \\
\hline $\mathrm{S}-\mathrm{H}_{0} 1$ & $\begin{array}{l}\text { The distribution of Support is the same } \\
\text { across categories of Gender. }\end{array}$ & $\begin{array}{l}\text { Independent-Samples } \\
\text { Mann-Whitney U Test }\end{array}$ & 0.421 & $\begin{array}{l}\text { Retain the null } \\
\text { hypothesis. }\end{array}$ \\
\hline $\mathrm{S}-\mathrm{H}_{0} 2$ & $\begin{array}{l}\text { The distribution of Support is the same } \\
\text { across categories of Hometown. }\end{array}$ & $\begin{array}{l}\text { Independent-Samples } \\
\text { Mann-Whitney U Test }\end{array}$ & 0.038 & $\begin{array}{l}\text { Reject the null } \\
\text { hypothesis. }\end{array}$ \\
\hline $\mathrm{S}-\mathrm{H}_{0} 3$ & $\begin{array}{l}\text { The distribution of Support is the same } \\
\text { across categories of Age Group. }\end{array}$ & $\begin{array}{l}\text { Independent-Samples } \\
\text { Kruskal-Wallis Test }\end{array}$ & 0.405 & $\begin{array}{l}\text { Retain the null } \\
\text { hypothesis. }\end{array}$ \\
\hline $\mathrm{S}-\mathrm{H}_{0} 4$ & $\begin{array}{l}\text { The distribution of Support is the same } \\
\text { across categories of Ethnicity. }\end{array}$ & $\begin{array}{l}\text { Independent-Samples } \\
\text { Kruskal-Wallis Test }\end{array}$ & 0.916 & $\begin{array}{l}\text { Retain the null } \\
\text { hypothesis. }\end{array}$ \\
\hline $\mathrm{S}-\mathrm{H}_{0} 5$ & $\begin{array}{l}\text { The distribution of Support is the same } \\
\text { across categories of Type of School. }\end{array}$ & $\begin{array}{l}\text { Independent-Samples } \\
\text { Kruskal-Wallis Test }\end{array}$ & 0.272 & $\begin{array}{l}\text { Retain the null } \\
\text { hypothesis. }\end{array}$ \\
\hline $\mathrm{S}-\mathrm{H}_{0} 6$ & $\begin{array}{l}\text { The distribution of Support is the same } \\
\text { across categories of Device Use. }\end{array}$ & $\begin{array}{l}\text { Independent-Samples } \\
\text { Kruskal-Wallis Test }\end{array}$ & 0.906 & $\begin{array}{l}\text { Retain the null } \\
\text { hypothesis. }\end{array}$ \\
\hline
\end{tabular}

Asymptotic significances are displayed at the level of 0.05 . 
An MLR analysis of the dependent variable Support and the independent variables (Gender, Location, Ethnicity, Age Group, School Type, Device Use, and perceptions on Quality, Opportunity, Relevance, Development, and Challenges)) in Table 19 showed that perception of Quality was the only significant predictor of participants' views on the student Support in the ODL at a significant level of $0.000<0.05$ and $\mathrm{R}^{2}$ of regression $=0.545$, and variance being significant at $\left.\mathrm{p}<0.05\right)$. None of the other independent variables were significant predictors of the participants' opinions on student Support in the ODL program at p $>0.05$. Four independent variables (Age3, Brahman, MobAndLap, and InsSchool) were excluded from the model because their tolerance values were all zeros making the variance inflation factor (VIF) infinitely large due to the potential existence of multiple collinearities among those variables (Table 19).

Table 19. MLR Analysis of Dependent Variable Support and Independent Variables (Gender, Location, Ethnicity, Age Group, School Type, Device Use and Perceptions of Quality, Opportunitity, Relevance,

Support, and Challenges)

\begin{tabular}{|c|c|c|c|c|c|c|c|c|}
\hline \multirow[t]{2}{*}{ Model } & \multirow[t]{2}{*}{$\begin{array}{l}\text { Model } \\
\text { Parameters }\end{array}$} & \multirow{2}{*}{$\begin{array}{c}\begin{array}{l}\text { Unstandardized } \\
\text { Coefficients }\end{array} \\
\text { B }\end{array}$} & \multicolumn{3}{|c|}{$\begin{array}{l}\text { Standardized } \\
\text { Coefficients }\end{array}$} & \multicolumn{3}{|c|}{ Collinearity Statistics } \\
\hline & & & $\begin{array}{l}\text { Std. } \\
\text { Error }\end{array}$ & Beta & $\mathrm{t}$ & Sig. & Tolerance & VIF \\
\hline \multirow[t]{6}{*}{5} & (Constant) & .193 & 1.270 & & .152 & .880 & & \\
\hline & Gender & -.151 & .290 & -.084 & -.522 & .604 & .337 & 2.970 \\
\hline & Hometown & -.220 & .190 & -.153 & -1.158 & .252 & .499 & 2.002 \\
\hline & Age2 & .188 & .230 & .107 & .818 & .417 & .509 & 1.966 \\
\hline & Age4 & .211 & .205 & .110 & 1.027 & .309 & .758 & 1.319 \\
\hline & Age 5 & -.384 & .564 & -.089 & -.682 & .498 & .515 & 1.942 \\
\hline \multirow{4}{*}{$\begin{array}{l}F(18,52)= \\
3.465, p<0.05 \\
R^{2}=0.54\end{array}$} & Kshetree & .166 & .199 & .095 & .835 & .407 & .681 & 1.469 \\
\hline & Baishya & .266 & .195 & .170 & 1.368 & .177 & .567 & 1.763 \\
\hline & Laptop & -.111 & .192 & -.071 & -.579 & .565 & .583 & 1.715 \\
\hline & Mobile Phone & .485 & .339 & .156 & 1.432 & .158 & .735 & 1.361 \\
\hline \multirow{4}{*}{$\begin{array}{l}\text { Excluded: Age3, } \\
\text { Brahman, Mob } \\
\text { and Laptop, Ins. } \\
\text { School }\end{array}$} & Desktop & .438 & .498 & .101 & .879 & .383 & .660 & 1.515 \\
\hline & Com. School & -.214 & .197 & -.125 & -1.085 & .283 & .661 & 1.514 \\
\hline & Pub. School & -.314 & .195 & -.197 & -1.606 & .114 & .579 & 1.727 \\
\hline & Other School & .037 & .346 & .015 & .107 & .915 & .422 & 2.372 \\
\hline \multirow{5}{*}{ (0 tolerance) } & Challenges & .085 & .108 & .087 & .788 & .434 & .717 & 1.395 \\
\hline & Quality & .548 & .138 & .538 & 3.968 & .000 & .476 & 2.100 \\
\hline & Opportunity & .230 & .163 & .181 & 1.410 & .164 & .533 & 1.876 \\
\hline & Relevance & -.207 & .202 & -.150 & -1.021 & .312 & .407 & 2.455 \\
\hline & Development & .250 & .164 & .202 & 1.528 & .133 & .499 & 2.003 \\
\hline
\end{tabular}

Dependent Variable: Support

\section{Perception of Challenges}

The participants were positive to the four (except one) items related to Challenges of the ODL in Nepal. The overall perception of graduate students on the challenges in the ODL was slightly higher than neutral $($ Mean $=3.35$ and Standard Deviation $=0.74)$. Their opinions about the challenges of the ODL program in Nepal indicated potential problems related to ICT skills and training for teachers and students and pedagogical competency of online instructors, but they rated neutral for the lack of ICT integration in the ODL curriculum as the difference of mean was not significant (Table 20 and Figure 7). 
Table 20. Descriptive Statistics and One-Sample t-Test for the Perception of Challenges in the ODL Courses

\begin{tabular}{lcrrrrr}
\hline \multicolumn{7}{c}{ One-Sample Statistics and Test at Population Mean = } \\
\hline Items & $\mathrm{N}$ & Mean & STD Dev & Mean Diff & t-Value & Sig. (two-tailed) \\
\hline C1 & 71 & 3.52 & 1.094 & .521 & 4.015 & .000 \\
C2 & 71 & 3.35 & 1.030 & .352 & 2.882 & .005 \\
C3 & 71 & 3.41 & 1.154 & .408 & 2.983 & .004 \\
C4 & 71 & 3.37 & .975 & .366 & 3.166 & .002 \\
C5 & 71 & 3.08 & 1.025 & .085 & .695 & .489 \\
\hline
\end{tabular}

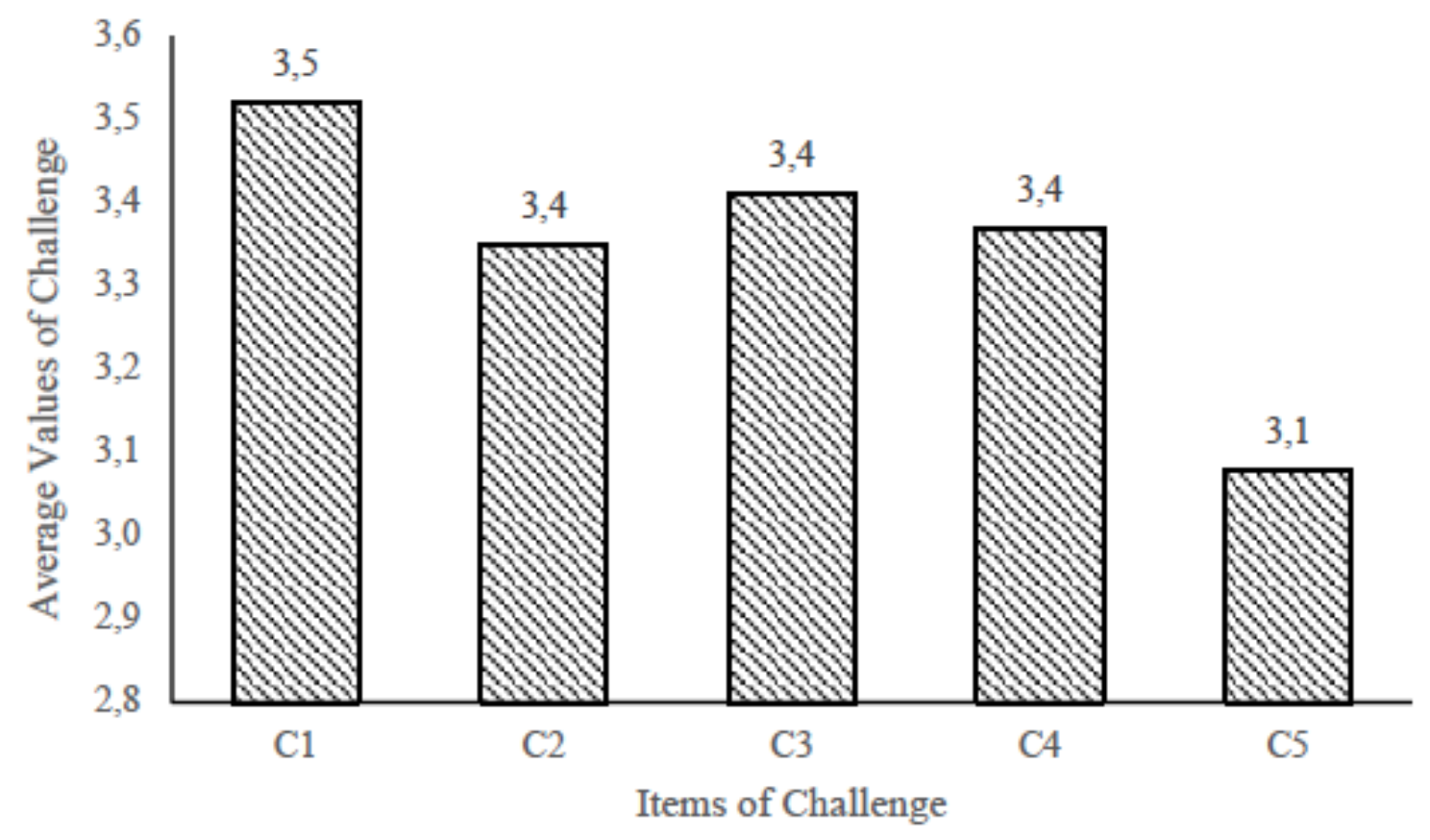

Figure 7. Average Value on Perception of Challenges in the ODL Courses

Independent-samples Man-Whitney U Test for the distribution of participants' perceptions on Challenges in the ODL courses across the Gender and Hometown showed no significant difference (Retain $\mathrm{C}_{-} \mathrm{H}_{0} 1$, C- $\left.\mathrm{H}_{0} 2\right)$ at 0.05 level of significance. Likewise, the Kruskal-Wallis Test showed no significant difference in the participants' perceptions of Challenges of the ODL across Age Groups, Ethnicity, School Type, and Device Use $(\mathrm{p}<0.05)$ (Retain C-H03, C-H04, C-H05, C-H06) (Table 21).

Table 21. Hypothesis Test on the Distribution of Perception of Challenges in ODL Courses across Gender, Hometown, Age Group, Ethnicity, School Type, and Device Use

\begin{tabular}{|c|c|c|c|c|}
\hline \multicolumn{2}{|r|}{ Null Hypothesis } & \multirow[t]{2}{*}{ Test } & \multirow[t]{2}{*}{ Sig. } & \multirow[t]{2}{*}{ Decision } \\
\hline Hyp. No. & Hypothesis & & & \\
\hline $\mathrm{C}-\mathrm{H}_{0} 1$ & $\begin{array}{l}\text { The distribution of Challenges is the same } \\
\text { across categories of Gender. }\end{array}$ & $\begin{array}{l}\text { Independent-Samples } \\
\text { Mann-Whitney U Test }\end{array}$ & 0.632 & $\begin{array}{l}\text { Retain the null } \\
\text { hypothesis. }\end{array}$ \\
\hline $\mathrm{C}-\mathrm{H}_{0} 2$ & $\begin{array}{l}\text { The distribution of Challenges is the same } \\
\text { across categories of Hometown. }\end{array}$ & $\begin{array}{l}\text { Independent-Samples } \\
\text { Mann-Whitney U Test }\end{array}$ & 0.754 & $\begin{array}{l}\text { Retain the null } \\
\text { hypothesis. }\end{array}$ \\
\hline $\mathrm{C}-\mathrm{H}_{0} 3$ & $\begin{array}{l}\text { The distribution of Challenges is the same } \\
\text { across categories of Age Group. }\end{array}$ & $\begin{array}{l}\text { Independent-Samples } \\
\text { Kruskal-Wallis Test }\end{array}$ & 0.352 & $\begin{array}{l}\text { Retain the null } \\
\text { hypothesis. }\end{array}$ \\
\hline $\mathrm{C}-\mathrm{H}_{0} 4$ & $\begin{array}{l}\text { The distribution of Challenges is the same } \\
\text { across categories of Ethnicity. }\end{array}$ & $\begin{array}{l}\text { Independent-Samples } \\
\text { Kruskal-Wallis Test }\end{array}$ & 0.407 & $\begin{array}{l}\text { Retain the null } \\
\text { hypothesis. }\end{array}$ \\
\hline
\end{tabular}




\begin{tabular}{lllll}
\hline $\mathrm{C}-\mathrm{H}_{0} 5$ & $\begin{array}{l}\text { The distribution of Challenges is the same } \\
\text { across categories of Type of School. }\end{array}$ & $\begin{array}{l}\text { Independent-Samples } \\
\text { Kruskal-Wallis Test }\end{array}$ & 0.493 & $\begin{array}{l}\text { Retain the null } \\
\text { hypothesis. }\end{array}$ \\
$\mathrm{C}-\mathrm{H}_{0} 6$ & $\begin{array}{l}\text { The distribution of Challenges is the same } \\
\text { across categories of Device Use. }\end{array}$ & $\begin{array}{l}\text { Independent-Samples } \\
\text { Kruskal-Wallis Test }\end{array}$ & 0.528 & $\begin{array}{l}\text { Retain the null } \\
\text { hypothesis. }\end{array}$ \\
\hline
\end{tabular}

Asymptotic significances are displayed at the level of 0.05 .

An MLR analysis of dependent variable Challenges and independent variables (Gender, Location, Ethnicity, Age Group, School Type, and Device Use and five perceptual variables in Table 22 showed only one independent variable of perception associated with Quality as significant to predict the participants' views about Challenges in the ODL program with $\mathrm{p}=0.007<0.05, \mathrm{R}^{2}$ regression $=0.291$, and variance being significant at $\mathrm{p}<0.05$ (Table 22). None of the other independent variables were significant predictors of the participants' opinions on their opinion on Challenges in the ODL program, as $p>0.05$. Four independent variables (Age2, Brahman, MobAndLap, and InsSchool) were excluded from the model because their tolerance values were all zeros making the variance inflation factor (VIF) infinitely large due to the potential existence of multiple collinearities among those variables (Table 22).

Table 22. MLR Analysis of Dependent Variable Challenges and Independent Variables (Gender, Location,

Ethnicity, Age Group, School Type, Device Use and Perceptions of Quality, Opportunity, Relevance,

Development, and Support)

\begin{tabular}{|c|c|c|c|c|c|c|c|c|}
\hline \multirow[t]{2}{*}{ Model } & \multirow[t]{2}{*}{$\begin{array}{l}\text { Model } \\
\text { Parameters }\end{array}$} & \multicolumn{2}{|l|}{$\begin{array}{l}\text { Unstandardized } \\
\text { Coefficients }\end{array}$} & \multicolumn{3}{|l|}{$\begin{array}{l}\text { Standardized } \\
\text { Coefficients }\end{array}$} & \multicolumn{2}{|l|}{$\begin{array}{l}\text { Collinearity } \\
\text { Statistics }\end{array}$} \\
\hline & & B & $\begin{array}{l}\text { Std. } \\
\text { Error }\end{array}$ & Beta & $\mathrm{t}$ & Sig. & Tolerance & VIF \\
\hline \multirow[t]{6}{*}{6} & (Constant) & 5.036 & 1.315 & & 3.830 & .000 & & \\
\hline & Gender & -.351 & .368 & -.191 & -.955 & .344 & .341 & 2.934 \\
\hline & Hometown & -.130 & .246 & -.088 & -.527 & .600 & .490 & 2.043 \\
\hline & Age3 & .373 & .291 & .250 & 1.282 & .205 & .357 & 2.799 \\
\hline & Age4 & -.114 & .369 & -.059 & -.310 & .758 & .381 & 2.623 \\
\hline & Age5 & .565 & .691 & .128 & .818 & .417 & .559 & 1.788 \\
\hline \multirow{5}{*}{$\begin{array}{l}F(18,52)= \\
1.188, p>0.05 \\
R^{2}=0.291\end{array}$} & Kshetree & -.320 & .252 & -.178 & -1.270 & .210 & .692 & 1.444 \\
\hline & Baishya & -.130 & .252 & -.081 & -.515 & 609 & .550 & 1.817 \\
\hline & Laptop & .078 & .246 & .048 & .316 & .753 & .580 & 1.723 \\
\hline & $\begin{array}{l}\text { Mobile } \\
\text { Phone }\end{array}$ & .364 & .438 & .115 & .830 & .410 & .716 & 1.396 \\
\hline & Desktop & -.132 & .640 & -.030 & -.207 & .837 & .651 & 1.537 \\
\hline \multirow{4}{*}{$\begin{array}{l}\text { Excluded: } \\
\text { Age2, } \\
\text { Brahman, Mob. } \\
\text { and Laptop, } \\
\text { Ins. School }\end{array}$} & Com. School & .054 & .254 & .031 & .213 & .832 & .647 & 1.547 \\
\hline & Pub. School & -.294 & .253 & -.181 & -1.165 & .249 & .566 & 1.766 \\
\hline & Other School & -.324 & .439 & -.132 & -.737 & .464 & .426 & 2.348 \\
\hline & Quality & -.528 & .188 & -.507 & -2.816 & .007 & .421 & 2.374 \\
\hline \multirow[t]{4}{*}{ (0 tolerance) } & Opportunity & .120 & .211 & .092 & .568 & .573 & .517 & 1.936 \\
\hline & Relevance & -.155 & .260 & -.110 & -.596 & .554 & .402 & 2.487 \\
\hline & Development & -.003 & .214 & -.002 & -.014 & .989 & .478 & 2.092 \\
\hline & Support & .139 & .176 & .136 & .788 & .434 & .460 & 2.174 \\
\hline
\end{tabular}

Dependent Variable: Challenges 


\section{DISCUSSION}

The present study analyzed the participants' views on the ODL in the Nepalese context based on six perceptual components - Quality, Opportunity, Relevance, Development, Support, and Challenges concerning independent variables Gender, Ethnicity, Age Group, Hometown, School Type, and Device Use. These perceptual dimensions of the ODL were derived from the principal component analysis of 40 items in the GSPODL questionnaire. This indicated that the graduate students' perceptions of the ODL were mostly related to the quality and relevancy of the program to provide opportunity of higher education and professional development of the working teachers in Nepal. The participants' perceptions were also aligned with the management aspects of the ODL, such as the challenges facing by the students in the ODL and the nature and quality of support they received from the institution.

Among the forty-two null hypothesis tested either by Mann-Whitney U Test or Kruskal-Wallis Test, only six were rejected at 0.05 level of significance. These results showed that the participants' views about Quality, Opportunity, Relevance, and Support were significantly different across their place of residence (rural and urban residences). Likewise, there was a significant difference in their views on the Relevancy of the ODL concerning Device Use. There was no significant difference in their views across the variables Gender, Ethnicity, School Type, and Device Use in all other criteria. These results demonstrate that participants' Hometown location makes a big difference in their perception of online and distance classes' quality. Internet connectivity in Nepal is yet to be improved at different places, especially out of urban areas. Since the ODL classes were run synchronous way in which all students and teachers had to be in the virtual class through the Microsoft Teams meeting platform, this connectivity through the virtual synchronous courses requires a good broadband Internet connection, which is still far from the rural areas where several research participants were staying. Even the asynchronous virtual classroom interaction needs a high bandwidth for such applications (Regmi, 2017). This issue is also related to the device students used during the virtual class sessions as some devices might not support high-definition videos for quality communication and interaction, leading to the significant difference among the participant views on Relevancy of the ODL.

Quality related perception of the participants showed that the quality of the ODL was better than the traditional face-to-face on-campus learning. However, they also agree that the availability of digital and other technical resources affected the quality of teaching and learning in the ODL program. The virtual online classes on the synchronous mode were not less effective than the face-to-face mode. That means, for the working teachers, the ODL provided them quality of education that was not, in many ways, less than the traditional mode of teaching-learning in the Nepalese context. However, the quality was significantly affected by the location of the students due to low Internet connection and lack of regular power supply. The perception of quality was not significantly different in other independent variables, such as gender, age-group, ethnicity, school type, and device use. While concerning the level of perception based on the different causal variables, age group (between 26-30 years), ethnicity (brahmin), and school type (community schools) were the relevant factors that can be attributed to forming positive or negative perceptions about the quality of the ODL in Nepal.

When the implementation of online and distance learning is concerned, Quality is always the most critical component to be considered. The quality of the ODL is always compared with the conventional mode of education to make decisions about investment in ICT infrastructure, human resources, and management of the teaching-learning system (Markova et al., 2017). Several studies compared the quality and effectiveness of the ODL and the face-to-face mode of education. They reported that learning in a distance or online manner can be equally valid or even more effective than the traditional pattern (Allen \& Seaman, 2014). The high Quality of the ODL can be attributed to students' self-study and independence in the study process, and gaining several skills that otherwise would be overshadowed in the face-to-face pattern. These skills are selfdependence, planning and organizing resources for study, appropriate time management based on individual needs, perseverance in problem-solving, taking self-responsibility, and working under multiple tasks context (e.g., family, job, and college course) (Markova et al., 2017). Such skills can be connected to e-learning that "offers multiple opportunities for self-regulated learning" (Paechter \& Maier, 2010, p. 296).

The participants in this study also rated high for the Opportunity related items indicating that they have considered the ODL as an opportunity for their learning and growth. The graduate students viewed that the 
course content, process, and context; the comfort of education, curriculum, interactive environment, flexibility, and scope of distance education all provided them with an opportunity to continue higher education while they were working full-time as school teachers at the different locations of Nepal. They seemed happy to have this opportunity to study from their own place through the online and distance education. They also felt that the classes were interactive and the curriculum helped them to organize their learning experiences by helping and supporting each other, despite being distant from each other. However, their perception of the opportunity was not the same across the locations. The reason might be the access of Internet and online platforms to classes from rural and remote places of Nepal where these facilities are limited or not adequate. Although the perception of participants about the opportunity of the ODL seemed very positive, there was not a single predictor that could accurately or reliably predict this variable among the independent variables, age group, gender, location, school type, ethnicity, and device use, except the feeling of the relevance of the program.

There is a widespread skepticism toward the effectiveness of online and distance education because it is still viewed as "inferior to face-to-face education" (Protopsaltis \& Baum, 2019, p. 30). Such skepticism has been stemmed from a lack of affordability, high cost, and lack of substantive interaction among the students and teachers during the online/distance learning. Despite these limitations and skepticism, ODL has gained popularity and expansion in recent years. The application of the ODL tools and techniques has been exponentially grown at the current moment due to the COVID-19 Pandemic. The majority of higher education institutions across the globe are going for a fully online and distant or blended mode of teachinglearning (Ali, 2020). Students at higher education institutions may consider the Relevancy of the ODL in terms of feeling connected, having shared feelings as members of the learning community, and continue learning through the synchronous and asynchronous communication with each other despite the physical distance from the educational institution (Swaggerty \& Broemmel, 2017).

The graduate students (research participants) found that the ODL was very relevant in the context of Nepal. The sense of the relevancy of the ODL was high due to flexibility of the delivery, access to the program from participants' place, use of devices such as computers or phones and other online technology and applications, professional connection (as school teachers), and continuous education despite being far from the university location while working at schools. However, there were two critical factors that affected their perception of the relevancy of the ODL with respect to their location where Internet and other services such as electricity supply were poor and the technological tools, such as dependency only on the phone due to lack of laptops or computers connected to the Internet. The graduate students' perception of the relevancy of the ODL in Nepal had a significant relationship with Gender, Hometown, Device (laptop), and School Type (other than private and public schools) as predicting variables. That means their perception of the relevancy of ODL could be predicted reliably with these independent variables. Likewise, their perception of the development and educational opportunities through the ODL could affect the degree of perception about the relevancy. It seems that the graduate students' perception of the relevancy of the ODL could be predicted (to some degree) with their feeling of the opportunity to develop in their teaching careers.

The online and distance learning (ODL) has been an alternative pathway for students who cannot afford regular face-to-face on-campus classes in several higher education institutions. Allen and Seaman (2014) reported a trend of online learning in the United States higher education institutions with the following questions-(1) Is online learning strategic?, (2) Are learning outcomes in online comparable to face-to-face?, (3) How many students are learning online?, and (4) What is the future of online learning? They reported that higher education institutions in the US strategically planned to expand their online learning programs from 2002 and onwards. A higher percent of the higher education institution leaders $(77 \%)$ agreed that online classes' outcomes are the same or superior to the on-campus face-to-face courses in 2012. This percent was a considerable increase from 57\% in 2003 (Allen \& Seaman, 2014). The number of students taking online classes has been increasing each year. In this context, a vast majority of the educational leaders firmly believed that the future of online education is broader with "selfdirected, self-paced components in future online courses" (Allen \& Seaman, 2014, p. 5).

Despite a growing trend of online and distance education at higher education institutions, there are mixed opinions of students about such programs. Yang and Cornelius (2004) reported students' perceptions of online learning to be affected by several factors, including flexibility, cost, electronic research, connectivity, class interface, feedback, technical support, student motivation, and nature of the course designed and delivered. 
There was a high sense of perception towards the developmental aspects of their careers as teachers while in the ODL program. They felt that the program helped them to enhance the quality of their education compared to their prior experience in higher education. This is a very critical factor that demonstrates how the ODL can play a significant role in professional growth and development in Nepal, provided the program is managed well and run properly. The ODL not only provided the participant teachers an opportunity to develop them through higher education, but it also helped them in improving teaching-learning in the classrooms. They developed a sense of independent learners through the ODL, enhancing their self-esteem through interaction among the students. There was no significant difference in their perception with respect to gender, age group, and other independent variables indicating that the degree of perception of development was not discriminated or varied concerning the grouping variables. Regarding the predictability of the perception of development through the ODL, only the age group (above 35 years) could be a significant predictor together with the feeling of relevance. Both the age group above 35 and sense of relevancy of the ODL seem to mutually affecting the sense of development because, after this age, there is a negative tendency to continue higher education and training for growth and development, maybe due to a sense of stability in the job and they don't think that they need further education for professional development. They might have the perception that education at this age was not very relevant due to overage.

In the present context of maintaining the flexible mode of training and Development in a higher education institution, the ODL provides an opportunity and resources for teachers' professional development through enhancing their pedagogical, content, and technological knowledge in addition to other kinds of skills, such as curriculum, classroom management, action research, to name a few (Shohel, 2012). "The emerging technology is going to be a solution for teachers' professional development in meeting the crisis of inadequate teacher supply in the Global South" (Shohel, 2012, p. 94). Nepal is one of such countries among the Global South where the government and higher education institutions have initiated teacher development through various means of the ODL, and it is even more evident in other areas as well due to the COVID-19 Pandemic in 2020. Therefore, school-based Support to teachers through the ODL has made it an effective way to improve their knowledge, skills, and attitudes in teaching-learning in Nepal. The participants' views and beliefs expressed that they have such support through the ODL courses.

The graduate students in the ODL had both positive and negative feelings regarding the support they received while in the program. They had a positive perception of the curriculum structure and other online learning resources in the context of Nepal and the clarity in objectives, course requirements, and assessment and grading system. However, they had a negative perception of the sufficiency of the learning materials provided during the synchronous teaching-learning hours. They felt that the teachers could not provide them sufficient tasks and study materials while in the class. Although, they had a positive feeling about technical and other support, and courserelated plans and activities, they seemed not happy with the teacher-created or provided materials. These views or perceptions were significantly different across their location of Hometown. The reason might be that the farther they were from the cities, the more difficulty they had with accessing these resources and supports through the institution and open sources as well. None of the variables in the study other than the quality aspects of the ODL was identified as a significant predictor of the graduate students' perception about support in the program.

The graduate students in the ODL program had a high sense of Challenges in terms of the ICT-related skills, instructor competency in ICT, ICT integration in classroom practices, and pedagogical competency of the course instructors. That means the graduate students who were in the ODL program faced challenges due to a lack of appropriate technical skills to use the information and communications (ICT) skill for teachinglearning purposes. This lack of skills was implied for both the students and teachers. The perception of the Challenges of the ODL was not significantly different across any grouping variables. That means all groups, such as Gender, Age group, Ethnicity and other grouping variables had similar level of challenges. Their perception of Challenges could be predicted reliably only with one variable, Quality, but not in an usual way as the unstandardized coefficient was negative. This result could be due to the sense of Quality negatively affecting the sense of Challenges, a high quality meant a low challenge due to ease of access and use, perceptually.

In addition to such opportunities for teacher Development in the ODL, some Challenges have been documented in the literature. For example, Wall (2012) outlined some challenges to be faced by teachers and students in ODL as technological challenges (tools, Internet, and connectivity), organizational challenges (managing time, persons, and resources), pedagogical challenges (teaching-learning through a variety of tools and applications and making both teachers and students ready to adapt with changes), and cultural challenges that arise from different social and cultural values, norms, and beliefs (Shakya, Sharma, \& Thapa, 2017). The participants in this study rated high for online instructors' pedagogical competency as a potential challenge in ODL, but they remained neutral with the nature of ICT integration in ODL. One of the reasons for being indifferent to ICT integration is that they might not have felt such integration as a challenge. Without such integration, ODL courses would not be delivered. 


\section{IMPLICATION, LIMITATION, AND CONCLUSION}

The findings of this study have pedagogical and policy implications in the context of ODL in Nepal. The pedagogical implications are related to Quality, Opportunity and Challenges as percieved by the graduate students. The Quality of ODL program directly affects the quality of students' learning and their professional development. Therefore, there should be revision of curriculum, self-learning materials, and quality of delivery modes through the synchronous and asynchronous means to fit with the ODL tools and learning contexts. There should be more Opportunities for students' interaction and participation through asynchronous media such as group chats, reflections on relevant topics, and sharing of ideas. These kinds of additional activities may provide learners Opportunities to constantly interact with each other and the instructors to build upon the ideas discussed in the synchronous classes. The students who are in the remote areas face Challenges in continuous learning through the synchronous mode of discussion. Therefore, the asynchronous mode of interaction will provide them more access to group activities and minimize the effect of challenges due to frequent disconnections of the Internet and power supply.

The policy implications of this study can be related to the Relevance, Development, and Support for the ODL programs, including students and teachers. The government of Nepal should focus on reforming the higher education for teachers by providing more access to the ODL programs while they are still working in schools. However, these programs should be made more relevant to their teaching practices and continuous professional development. Likewise, the distance education policy should be reformed and updated with the current needs of working teachers and other professionals to develop their careers as well as to develop the institutional infrastructure of the ODL programs. For this, there should continuous Support from the government and the public to enhance the quality of ODL in Nepal. The findings of this study contributed to the knowledge of ODL processes in developing and underdeveloped countries. The lessons learned from this study can support in the pedagogical and policy reforms in other similar contexts and countries.

There were several limitations while conducting this study. One of the most critical limitations was the sample size. Altogether, there were 94 students enrolled in the Master of Education in Science Education program at Mahendra Ratna Campus Tahachal, Kathmandu Nepal through the ODL mode, who were our study subjects. Since the participation of the survey was not a part of the course work, and it was a voluntary action, only 71 were able to fill up the online survey (GSPODL-scale) in Google Form through a link distributed through Microsoft Teams virtual classroom platform. This sample size is small to generalize the study results in other contexts. Despite this limitation, the study result has suggested some critical ideas, such as the six components of participants' perceptions of the ODL in terms of Quality, Opportunity, Relevance, Development, Support, and Challenges.

The programs of online and distance education in Nepal should acknowledge the students' learning experiences in terms of the quality of the program and support system. The graduate students have positive feelings about the program regarding new educational opportunities to develop their professional careers as school teachers. The programs, such as the ODL, should be designed to make the courses relevant to the professionals in terms of the use of ICT and relevant resources despite the challenges of geophysical and technological infrastructure in remote areas of Nepal. These kinds of programs are also helpful for professionals to develop their self-efficacy on independent learning and professional development through both synchronized and asynchronized online and distance education programs. Each of the areas indicated in this study-- Quality, Opportunity, Relevance, Development, Support, and Challenges were the significant concerns in the ODL courses and programs at higher education institutions in Nepal. Improving these areas will impart a positive impression and broader participation through enhanced metacognition of the students and teachers of the ODL in Nepal and elsewhere. It is recommend that further study should be carried out on the effectiveness of different online applications and programs on student performance through distance learning.

Acknowledgements: We would like to acknowledge the support from the administration of Mahendra Ratna Campus Tahachal, Tribhuvan University, Kathmandu Nepal for helping us during the data collection. We would like to thank all the participants who participated in the survey. We are grateful to anonymous reviewers for their constructive feedback to bring the article in the current form. 


\section{BIODATA AND CONTACT ADDRESSES OF AUTHORS}

Parshu Ram UPADHAYAYA is an assistant professor in the Department of \& Information and Communication Technology (ICT) Education at Butwal Multiple Campus, Tribhuvan University, Nepal. He is an M.Phil. Scholar at Nepal Open University. He earned his M.Ed. in Information and Communication Technology (ICT) Education from Tribhuvan University. He teaches educational technology related courses and supervises preservice teachers' practicum teaching. His research interest is interface between technology and learners and how they interact and affect each other. His current research focuses on use of online tools in distance teahcing and learning.

Parshu Ram UPADHAYAYA

Department of Information and Communication Technology (ICT) Education

Address: Butwal Campus, Tribhuvan University, Nepal.

Phone: +9779851165697

Email: parshuram@mrctu.edu.np

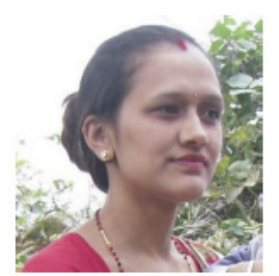

Bishnu SHARMA is an Assistant Professor of Education in the Central Department of Education at Tribhuvan University, Kathmandu, Nepal. She earned her M. Phil and M.Ed. degrees in Education from Tribhuvan University. She supervises preservice teachers' practicum teaching and thesis writing in addition to teaching courses of curriculum practices and foundation of education. She has published research articles in national and international peer reviewed journals and presented her works in conferences. Her current research interest focuses on curriculum issues and women participation in decision making in education sector in Nepal.

Bishnu SHARMA

Central Department of Education

Address: Tribhuvan University, Kathmandu

Phone: +9779849146667

Email: bishnu.sharma@tucded.edu.np

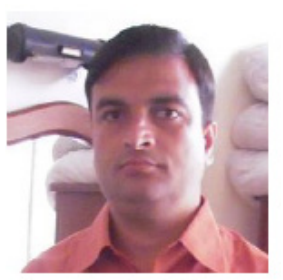

Yagya Prasad GNAWALI is an Assistant Professor at Mahendra Ratna Campus Tahachal, Tribhuvan University, Kathmandu, Nepal. He is a Ph.D. Scholar at Graduate School of Education, Tribhuvan University. He earned his M.Ed. in Mathematics Education from Tribhuvan University. He teaches content and pedagogical courses of mathematics education for bachelor and master's classes. In addition to teaching, he also supervises preservice teachers' practicum teaching. His research interest is teacherlearner autonomy and accountability in mathematics classroom.

Yagya Prasad GNAWALI

Department of Mathematics Education

Address: Mahendra Ratna Campus Tahachal,

Tribhuvan University, Kathmandu

Phone: +9779851135729

Email: gnawali.yagya@gmail.com 


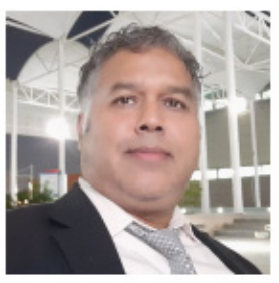

Dr. Shashidhar BELBASE is an assistant professor in the Department of Curriculum and Instruction in the College of Education at United Arab Emirates University. $\mathrm{He}$ earned Ph.D.in Mathematics Education from the University of Wyoming. He teaches undergraduate and graduate courses of mathematics education and research methods. His research interest ranges from teacher and student beliefs about teaching-learning mathematics with technology, interdisciplinary STEM/STEAM education, and other cross-cutting issues of education and environment.

Shashidhar BELBASE

Department of Curriculum and Instruction

Address: College of Education, United Arab Emirates University

Post Box No. 15551, Al Ain, Abu Dhabi, United Arab Emirates

Phone: +971 528588151

Email: sbelbase@uaeu.ac.ae

\section{REFERENCES}

Ali, W. (2020). Online and remote learning in higher education institutes: A necessity in the light of COVID-19 pandemic. Higher Education Studies, 10(3), 16-25. DOI: https://doi.org/10.5539/ hes.v10n3p16

Allen, I. E., \& Seaman, J. (2014). Grade change: Tracking online education in the United States. Babson Survey Research Group and Quahog Research Group, LLC. Online accessed on July 19, 2020 from: http://www.onlinelearningsurvey.com/reports/gradechange.pdf

Behrend, T. S., Sharek, D. J., Meade, A. W., \& Wiebe, E. N. (2011). The validity of crowdsourcing for survey research. Behavior Research, 43, 800-813. DOI: https://doi.org/10.3785/s13428-011-0081-0.

Cabi, E., \& Kalelioglu, F. (2019). A fully online course experience from students' perspective: Readiness, attitudes and thoughts. Turkish Online Journal of Distance Education-TOJDE, 20(3), 165-180.

Chouhan, T. (2014). Distance education for computers undeveloped country like in Nepal: prospects and challenges. International Journal of Information and Education Technology, 4(6), 463-467.

Creswell, J. W. (2012). Educational research planning, conducting and evaluating quantitative and qualitative research ( $4^{\text {th }} \mathrm{ed}$.). United State: Pearson Education Inc.

Demiray, U., \& Isman, A. (2001). History of distance education. Sakarya Universitesi Egitim Fakultesi Dergisi [Sakarya University Faculty of Education Journal], 1(1), 88-108.

Dhakal, M. (Dec. 30, 2019). Open university boon for students working, living far away. The Rising Nepal: The First and Foremost National Daily, Dec. 30, 2020. Online accessed on July 20, 2020 from: https://risingnepaldaily.com/nation/open-university-boon-for-students-working-living-far-away

Drexel University. (2017). A brief history of distance education and learning (online video). Online accessed from: https://www.online.drexel.edu/history-of-distance-learning.aspx

Firat, M. (2016). Measuring the e-learning autonomy of distance education students. Open Praxis, 8(3), 191-201.

Government of Nepal (GoN). (2016). Nepal Open University Act 2016. Singhdurbar, Kathmandu: GoN. Accessed on July 15, 2020 from: https://nou.edu.np/university-actrulespolicynotice

Gunawardena, C. N., \& McIsaac, M. S. (2008). Distance education. In D. H. Jonnasen (Ed.), Handbook of research on educational communications and technology (2 ${ }^{\text {nd }}$ ed.) (pp. 355-396). Mahwah, NJ: Lawrence Erlbaum Associates, Publishers.

Gunduz, M. E., Kursun, E., Karaman, S., \& Demirel, T. (2020). Problems, expectations, and amendments regarding distance education legislation in higher education institutions in Turkey. Turkish Online Journal of Distance Education- TOJDE, 21(4), 173-194. 
Holmes, D. R. (1990). Education through radio in Nepal: Changes within and beyond the classroom. Himalayan Research Bulletin no. 2 \& 3, 10(2-3), 24-29.

Institute of Open Learning (IOL). (2020). Introduction. Online accessed: http://www.iol.edu.np/about.php International Center for Academics (ICA). (2020). All courses available in ICA. Online accessed from: https://ica.edu.np/courses

Kathmandu University School of Education (KUSOED). (2020 a). Master of Education in English language teaching (M Ed in ELT) One year program: The curriculum (Approved by the 121 $1^{\text {st }}$ meeting of the Academic Council held on 30th June 2020). Hattiban, Lalitpur: KUSOED. Online accessed on July 18, 2020 from: http://soe.kusoed.edu.np/one-year-m-ed-in-english-language-teaching/

Kathmandu University School of Education (KUSOED). (2020 b). Guideline for online teaching and learning. Hattiban, Lalitpur: KUSOED. Accessed online on July 19, 2020 from: http://soe.kusoed.edu.np/ guidelines-for-online-teaching-and-learning/

Kemp, N. (2019). Higher education's distance learning delivery dilemma. University World News: The Global Window on Higher Education. Accessed on July 22, 2020 from: https://www.universityworldnews. com/post.php?story=20190926083339425

Kentnor, H. E. (2015). Distance education and the evolution of online learning in the United States. Curriculum and Teaching Dialogue, 17(1 \& 2), 21-34.

Lee, B., Yoon, J. O., \& Lee, I. (2009). Learners' acceptance of e-learning in South Korea: Theories and results. Computers and Education, 53(1), 1320-1329.

Markova, T., Glazkova, I., \& Zabarava, E. (2017). Quality issues on online distance learning. Social and Behavioral Sciences, 237(1), 685-691.

Ministry of Education (MoE). (2007). Open and distance learning (ODL) policy 2007. Singhdurbar, Kathmandu: Government of Nepal, Ministry of Education.

Ministry of Education, Science, and Technology (MoEST). (2020). Learning portal. Singhdurbar, Kathmandu: MoEST. Accessed from: https://learning.cehrd.edu.np/

Ministry of Human Resource Development (MHRD), Government of India. (2020). Distance learning: State open universities (SOUs). New Delhi: MHRD. Online accessed on July 22, 2020 from: https://mhrd.gov.in/technology-enabled-learning-sou

Molenda, M. (2008). Historial foundations. In J. M. Spector, M. D. Merrill, J. V. Merrienboer \& M. P. Driscoll (Eds.), Handbook of research on educational communications and technology (3 $3^{\text {rd }} \mathrm{ed}$.) (pp. 3-20). New York, NY: Routledge.

National Center for Education Statistics (NCES). (2019). Distance learning. FAST FACTS. Online accessed from: https://nces.ed.gov/fastfacts/display.asp?id=80

Nepal Open University. (2020). Our faculties. https://nou.edu.np/

Open and Distance Education Center. (2020). Introduction to Online and Distance Education Center (ODEC). Kirtipur, Kathmandu: Tribhuvan University. Accessed on July 15, 2020 from: http:// wp.odectu.edu.np/introduction/

Paechter, M., \& Maier, B. (2010). Online or face-to-face? Students' experiences and preferenes in e-learning. Internet and Higher Education, 13(2010), 292-297.

Pangeni, S. K. (2016). Open and distance learning: Cultural practices in Nepal. European Journal of Open, Distance and e-Learning, 19(2), 32-45.

Pradhan, L. (2011). Distance education in Nepal. Paper presented at the $1^{\text {st }}$ International Technology, Education, and Environment Conference, African Society for Scientific Research (ASSR) (pp. 320-324). Online accessed on July 20, 2020 from: http://hrmars.com/admin/pics/240.pdf

Protopsaltis, S., \& Baum, S. (2019). Does online education live up to its promise?: A look at the evidence and implications for federal policy. Geormason University. Online accessed on July 19, 2020 from: https://mason.gmu.edu/ -sprotops/OnlineEd.pdf 
Qayyum, A., \& Zawacki-Richter, O. (2019). The state of open and distance education. In O. ZawackiRichter \& A. Qayyum (Eds.), Open and distance education in Asia, Africa, and the Middle East: National perspectives in a digital age (pp. 125-140). Singapore: Springer Open.

Regmi, N. (2017). Expectations versus reality: A case of Internet in Nepal. The Electronic Journal of Information System in Developing Countries, 82(7), 1-20.

Reich, J., \& Tobias, J. L. (2020). Evaluating access, quality and equity in online learning: A case study of a Mooc-based blended professional degree program. The Internet and Higher Education, 47, 1-11.

Richards, H. M., \& Schwartz, L. J. (2002). Ethics of qualitative research: Are there special issues for health services research? Family practices, 19(2),135-139.

Sapkota, S. (2012). Teacher education through distance mode: The Nepalese experience. PhD dissertation, The Open University, UK.

Serhii, V., Vladyslav, K., Viacheslav, O., Kateryna, O., \& Svitlana, S. (2020). Realities and prospects of distance learning at higher education institutions of Ukraine. Ukrainian Journal of Educational Studies and Information Technology, 8(1), 1-16.

Shakya, S., Sharma, G., \& Thapa, K. B. (2017). State education system with e-learning in Nepal: impact and challenges. Journal of Institute of Engineering, 31(1), 10-19.

Shohel, M. C. (2012). Open and distance learning for teachers' professional development: The English in action (EIA) model for the Global South. In J. L. Moore \& A. D. Benson (Eds.), International perspectives of distance learning in higher education (pp. 93 - 108). Rijeka, Croatia: In Tech.

Suneja, K. (May 4, 2012). 25\% of Indian students covered by distance education: Study. Financial Express (May 4, 2012). New Delhi, India. Online accessed on July 22, 2020 from: https://www.financialexpress. com/archive/25-of-indian-students-covered-by-distance-education-study/945204/

Swaggerty, E. A., \& Broemmel, A. D. (2017). Authenticity, relevance, and connectedness: Graduate students' learning preferences and experiences in an online reading education course. Internet and Higher Education, 32(2017), 80-86. DOI: http://dx.doi.org/10.1016/j.iheduc.2016.10.02

Trespalacios, J., Uribe-Florez, L. J. (2020). Developing online sense of community: Graduate students' experiences and perceptions. Turkish Online Journal of Distance Education-TOJDE, 21(1), 57-72.

Vasilevska, D., Rivza, B., Pivac, T., Alekneviciene, V., \& Parlinska, A. (2017). Analysis of the demand for distance education as eastern and central European higher education institutions. Journal of Teacher Education for Sustainability, 19(1), 106-116.

Wall, J. (2012). Strategically integrating blended learning to deliver lifelong learning. In J. L. Moore \& A. D. Benson (Eds.), International perspectives of distance learning in higher education (pp. 133 - 148). Rijeka, Croatia: In Tech.

Yang, Y., \& Cornelius, L. F. (2004). Students' perception toward the quality of online education: A qualitative approach. Association of Educational Communication and Technology, 27 th Annual Meeting, Chicago, IL. Oct. 19-23, 2004. 


\section{APPENDIX}

\section{Questionnaire}

\section{Graduate Students' Perception of Online and Distance Learning (GSPODL) in Nepal}

Please, select your response to the following statement, where, $\mathrm{SD}=$ Strongly Disagree, $\mathrm{D}=$ Disagree, $\mathrm{N}=$ Neutral, A = Agree, and SA = Strongly Agree.

\begin{tabular}{|c|c|c|c|c|c|}
\hline Items & SD & D & $\mathbf{N}$ & A & SA \\
\hline $\begin{array}{l}\text { 1. I feel that ODL has provided us a good learning experience and opportunity with } \\
\text { flexible learning time and place. }\end{array}$ & & & & & \\
\hline 2. The use of assistive technologies helps to meet my learning needs. & & & & & \\
\hline $\begin{array}{l}\text { 3. The curriculum has been designed in a way that we have opportunity to organize } \\
\text { activities on the online mode delivery structure. }\end{array}$ & & & & & \\
\hline $\begin{array}{l}\text { 4. The current curriculum implemented by ODL provides us opportunity of higher } \\
\text { education through distance learning. }\end{array}$ & & & & & \\
\hline $\begin{array}{l}\text { 5. The classes on virtual online mode are as effective as the face-to-face mode } \\
\text { classes in terms of quality. }\end{array}$ & & & & & \\
\hline $\begin{array}{l}\text { 6. The ODL classes create interactive environment for both teachers and students } \\
\text { with opportunity to interact and support each other.. }\end{array}$ & & & & & \\
\hline $\begin{array}{l}\text { 7. The ODL courses provide students and teachers opportunities to integrate } \\
\text { content, process, and context while working within a variety of cooperative } \\
\text { learning groups. }\end{array}$ & & & & & \\
\hline $\begin{array}{l}\text { 8. The ODL materials are sufficient, as you have been provided by teacher, in online } \\
\text { platform such as Moodle, Google Classroom, Microsoft Teams, etc. }\end{array}$ & & & & & \\
\hline $\begin{array}{l}\text { 9. Online classes are comfortable for me as I have an opportunity to study from my } \\
\text { own place. }\end{array}$ & & & & & \\
\hline $\begin{array}{l}\text { 10. Due to the limited resources, the students are unable to participate in the class } \\
\text { well. }\end{array}$ & & & & & \\
\hline $\begin{array}{l}\text { 11. The ODL classes are effectively conducted on time using relevant online } \\
\text { technology. }\end{array}$ & & & & & \\
\hline $\begin{array}{l}\text { 12. The ODL teaching techniques provoke self-learning and independent learning to } \\
\text { develop my skills. }\end{array}$ & & & & & \\
\hline $\begin{array}{l}\text { 13. There is sufficient interaction between students and teachers and among the } \\
\text { students while teaching learning in an online class. }\end{array}$ & & & & & \\
\hline $\begin{array}{l}\text { 14. The teaching techniques in online classes motivate me for independent learning } \\
\text { and development. }\end{array}$ & & & & & \\
\hline $\begin{array}{l}\text { 15. In the ODL system, the structure of curriculum and delivery system support } \\
\text { students'learning. }\end{array}$ & & & & & \\
\hline $\begin{array}{l}\text { 16. There is a lack of trained teaching manpower for ODL program implementation } \\
\text { that has affected the quality.. }\end{array}$ & & & & & \\
\hline $\begin{array}{l}\text { 17. There is a lack of motivation among educators to adopt and integrate ICT as a tool } \\
\text { into their teaching or educational curriculum. }\end{array}$ & & & & & \\
\hline $\begin{array}{l}\text { 18. The ODL teaching model helps teachers and students to analyze and solve } \\
\text { relevant problems related to connectivity and delivery of the lessons. }\end{array}$ & & & & & \\
\hline 19. The use of ICT tools in ODL is relevant and motivates me in study. & & & & & \\
\hline $\begin{array}{l}\text { 20. English is the dominant language on the internet, so language is the challenge of } \\
\text { integrating ICTs use in the education system. }\end{array}$ & & & & & \\
\hline $\begin{array}{l}\text { 21. The ODL online education is relevant in my professional development to be a } \\
\text { competent teacher. }\end{array}$ & & & & & \\
\hline $\begin{array}{l}\text { 22. The ODL online classes help me to fulfill several teaching-learning purposes for } \\
\text { my profession. }\end{array}$ & & & & & \\
\hline $\begin{array}{l}\text { 23. The ODL program helps me to increase the quality of education as compared to } \\
\text { former degree. }\end{array}$ & & & & & \\
\hline
\end{tabular}




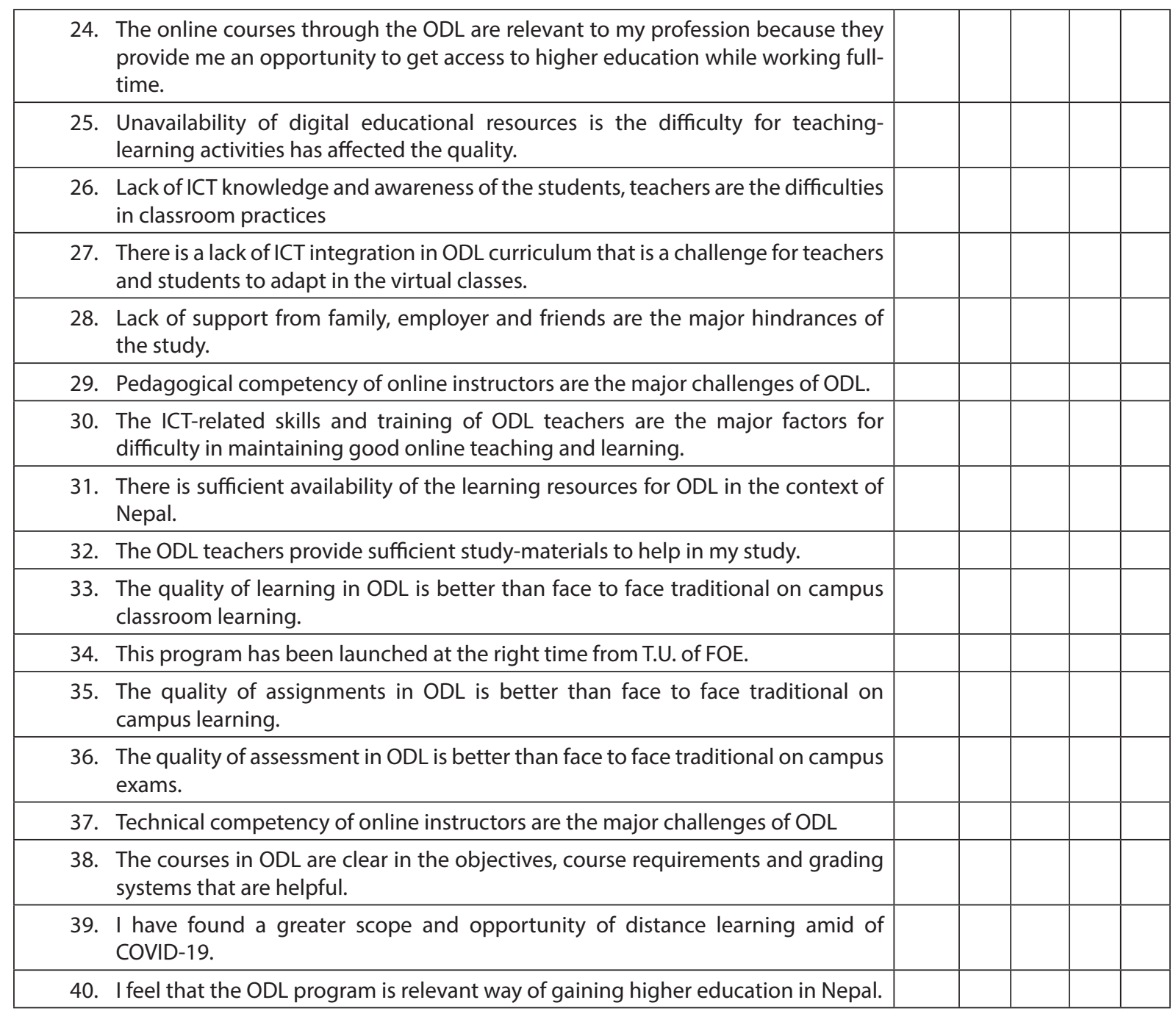

